\title{
Novel In-Situ Metal and Mineral Extraction Technology
}

\author{
Final Report \\ 9/30/03 through $9 / 22 / 04$ \\ Glenn O'Gorman, Hans von Michaelis, and Gregory J. Olson
}

Report Issued: September 22, 2004

DOE Award Number: DE-FG26-03NT41937

Submitting organization:

Little Bear Laboratories, Inc., 5906 McIntyre St., Bldg. 2, Golden, CO 80403

Subcontractors:

Glenn O'Gorman, Orem, Inc.

Hans von Michaelis, Randol International Ltd. 
DISCLAIMER: This report was prepared as an account of work sponsored by an agency of the United States Government. Neither the United States Government nor any agency thereof, nor any of their employees, makes any warranty, express or implied, or assumes any legal liability or responsibility for the accuracy, completeness, or usefulness of any information, apparatus, product, or process disclosed, or represents that its use would not infringe privately owned rights. Reference herein to any specific commercial product, process, or service by trade name, trademark, manufacturer, or otherwise does not necessarily constitute or imply its endorsement, recommendation, or favoring by the United States Government or any agency thereof. The views and opinions of authors expressed herein do not necessarily state or reflect those of the United States Government or any agency thereof. 


\begin{abstract}
This white paper summarizes the state of art of in-situ leaching of metals and minerals, and describes a new technology concept employing improved fragmentation of ores underground in order to prepare the ore for more efficient in-situ leaching, combined with technology to continuously improve solution flow patterns through the ore during the leaching process. The process parameters and economic benefits of combining the new concept with chemical and biological leaching are described. A summary is provided of the next steps required to demonstrate the technology with the goal of enabling more widespread use of in-situ leaching.
\end{abstract}




\section{TABLE OF CONTENTS}

EXECUTIVE SUMMARY

$\begin{array}{ll}\text { 1. INTRODUCTION } & 6\end{array}$

2. OBJECTIVES 8

3. APPLICATIONS OF IN-SITU LEACHING 9

4. BENEFITS OF IN-SITU LEACHING 17

5. SHORTCOMINGS AND DISADVANTAGES OF IN-SITU LEACHING 18

6. GENERAL DESCRIPTION OF IN SITU LEACHING AND INTEGRATION OF 20 THE NEW CONCEPT WITH CHEMICAL AND BIOLOGICAL EXTRACTION

7. IN-SITU LEACHING PATENTS 39

8. DETAILED DESCRIPTION OF THE NEW CONCEPT 45

9. ECONOMICS OF THE NEW CONCEPT 50

10. BENEFITS OF THE NEW CONCEPT 54

11. WHAT NEEDS TO BE DONE NEXT 55

12. SUMMARY AND CONCLUSIONS 56

13. REFERENCES AND LIST OF IN-SITU LEACH EXPERTS 57

14. APPENDIX (FIGURES ILLUSTRATING NEW CONCEPT) 62 


\section{EXECUTIVE SUMMARY}

Decreasing grades of near-surface deposits has resulted in mining, transport, and processing of immense volumes of rock per unit of product recovered. Large-scale low-grade open pit mining projects have been made possible by the availability of huge mining and mineral processing machinery capable of supporting operations on a very large scale. Key to economic viability of such large-scale low-grade operations has undoubtedly been the availability of abundant low cost energy, i.e. diesel fuel and electricity. The future availability of low cost energy is in question. Also, widespread exploration for open pit mineable deposits has resulted in the discovery of mineral deposits that cannot be economically exploited by conventional mining techniques because the strip ratio is too high, the deposit is too small to repay the required capital investment, and/or the grade too low. In an increasing number of jurisdictions the large footprint and high visibility of open pit mining operations and their related waste disposal facilities are finding resistance from local communities. Cost, safety, waste disposal and water quality issues are also becoming increasingly important in the underground mining of deeper deposits.

As a result of these issues, in-situ leaching (ISL) is receiving renewed attention as a technology that could be used to extract metals from ores more cheaply with less environmental impact and using far less energy than conventional mining. However, the current state of technology of in-situ leaching limits its application due to low metal recoveries resulting from poor solution contact with ore, long leaching times, poor aeration, and loss of leach solution into the surrounding rock which has both economic and environmental liabilities. Consequently, technical improvements must be made in order for in-situ leaching to find more widespread application.

This white paper focuses on application of an innovative approach to in-situ ore fragmentation, progressively changing the flow patterns of lixiviant through the fractured ore as a means of eliminating channeling of solutions and improving the contact of solutions with the ore being leached, a means of providing simple, cheap and effective oxygenation of the in-situ ore, as a means of controlling reaction rates, and a solution collection system that virtually eliminates the potential for fugitive solution loss to the environment.

The mining and extraction process proposed herein contemplates establishing a system of underground drawpoints beneath a leachable deposit from which a slot raise (or raises) is driven to the surface to act as a primary opening for blasting the entire deposit as a single event and undertaking in-situ leaching of the entire deposit over a very long time period. It is envisaged that the leaching process would continue for many years until either all leachable material has been extracted or the daily recovered metal revenue decreases to a point where it is less than operating costs.

It is recognized that the new technology described in this white paper will not be universally applicable for in-situ leaching, but will apply initially to relatively near surface deposits that conform to a somewhat specific geometry.

This white paper reviews the past commercial applications of in situ leaching technology, the relevant patents, the benefits and drawbacks of this technology, a general description of the current status of the technology, a detailed description of the new concept with a preliminary economic assessment, how the new concept may be integrated with chemical and biological leaching technology, and a summary of future directions. 


\section{INTRODUCTION}

In-situ mining according to Bates and Jackson (1987), a definition endorsed by the National Academy of Sciences (2002), is the "removal of the valuable components of a mineral deposit without physical extraction of the rock". The American Geological Institute defines insitu leaching as a type of in-situ mining in which metals or minerals are leached from rocks by aqueous solution, a hydrometallurgical process. This white paper describes and explores the potential applicability of a new concept that offers improvements in the state of the art of in-situ leaching.

Decreasing grades of near-surface deposits has resulted in mining, transport, and processing of immense volumes of rock per unit of product recovered (Liu and Brady, 1998). Large-scale low-grade open pit mining projects have been made possible by the availability of huge mining and mineral processing machinery capable of supporting operations on a very large scale. Key to economic viability of such large-scale low-grade operations has undoubtedly been the availability of abundant low cost energy, i.e. diesel fuel and electricity. The future availability of low cost energy is in question. Also, widespread exploration for open pit mineable deposits has resulted in the discovery of mineral deposits that cannot be economically exploited by conventional mining techniques because the strip ratio is too high, the deposit is too small to justify the required capital investment, and/or the grade too low. In an increasing number of jurisdictions the large footprint and high visibility of open pit mining operations and their related waste disposal facilities are finding resistance from local communities. Cost, safety, waste disposal and water quality issues are also becoming increasingly important in the underground mining of deeper deposits. In-situ leaching has demonstrated lower cost uranium production in Wyoming, Texas, Eastern Europe and Russia compared with conventional mining and processing. Consequently, in-situ mining, more specifically in-situ leaching, is expected to play a greater role in mining within the next 15 to 20 years (Batterham, 2004). The technology needs to be broadened for application possibly to other metal deposits, e.g copper porphyry, buried volcanogenic massive sulfides, sediment hosted and/or carbonate replacement metal sulfide deposits as well as gold and silver deposits, buried placer deposits, nickel laterites, etc.

A number of challenges must be met before in-situ leaching can be more widely applied. The overall goal of this white paper is to identify these challenges, and to further explore and develop a new concept that advances the technology of in-situ leaching in a manner that addresses at least some of them.

Uranium extraction from porous sandstone deposits by in-situ leaching has been reported to achieve recoveries in the $60 \%$ to $90 \%$ range. If true, that would be quite good, but in-situ leach recoveries are very hard to measure and such recovery claims need to be verified. One of the major constraints of in-situ leaching of copper from porphyry deposits using known technology is the relatively low expected recovery of metal. The US Bureau of Mines experimental in-situ leaching of copper from a buried porphyry deposit at Casa Grande, New Mexico reputedly yielded negligible recoveries. Young (2000b, personal communication) estimated that at the San Manuel in-situ operation in Arizona, recovery rates of copper from caved areas already mined was of the order of $50 \%$ to $60 \%$ over five years, but, again, it was almost impossible to determine recovery with any accuracy. The innovative new approach described in this white paper aims to improve in-situ leach recovery of metals and thereby to enhance the applicability of in-situ leaching. 
Copper is currently successfully leached in-place from rubblized ore on the sides of an open pit at ASARCO's Silver Bell copper mine in Arizona. Copper recoveries thus far have been low, of the order of $20 \%$ to $25 \%$, but believed to be economically viable nonetheless.

This white paper focuses on application of an innovative approach to in-situ ore fragmentation, progressively changing the flow patterns of lixiviant through the fractured ore as a means of eliminating channeling of solutions and improving the contact of solutions with the ore being leached, a means of providing simple, cheap and effective oxygenation of the in-situ ore, and means of controlling reaction rates, and a solution collection system that virtually eliminates the potential for fugitive solution loss to the environment.

In-situ leaching has been touted as being more environmentally desirable because of the minimal surface expression of the activity compared with conventional mining. Increasing concern for preservation of groundwater quality, however, requires that particular attention be paid to what occurs below the surface.

Over the last three decades or so, the technology of heap leaching (particularly for the extraction of copper, gold and silver) has advanced by leaps and bounds. Heap leaching was originally developed for the treatment of oxidized copper, gold and uranium ores. More recently, heap leaching has become increasingly applicable for the extraction of copper from sulfide ores, particularly those in which copper occurs in chalcocite. In addition, the technology is being extended to leaching of nickel and zinc.

Bioheap leaching of copper from sulfide ores has also made significant advances. Brierley \& Brierley (2000) summarized the results for ten commercial heap leaching operations treating chalcocite copper ores. Eight of theses are in Chile and two in Australia. Bruynesteyn (2000) and Young (1999) reported progress in developing technology for bio-leaching chalcopyrite.

The in-situ leach concept that is the focus of this white paper lends itself to the application of the same leaching technology used for heap leaching and bioheap leaching, but applied to selected deposits that cannot be economically mined by conventional techniques. In addition the new in-situ leach technology promises to create a means of optimizing the leach process even beyond that possible in conventional run-of-mine heap leaching. 


\section{OBJECTIVES}

Specific objectives of this white paper are:

1) Summarize the state of the art of in-situ leaching of metals and minerals.

2) Elucidate some of the limitations and challenges of in-situ leaching.

3) Delineate a new technology concept for improving the efficiency of in-situ leaching.

4) Define, at least in broad terms, the economics (capital and operating costs) of the new insitu leaching system.

5) Delineate process parameters and potential further economic benefits of combining the improved in-situ leaching concept with in-situ bio-oxidation of sulfide base metal ores.

6) Provide a strategy or road map for future $R \& D$ efforts focused on applying these concepts to demonstrate the potential for more widespread use of in-situ leaching. 


\section{APPLICATIONS OF IN-SITU LEACHING}

There are references to primitive forms of in-situ leaching of copper in Roman times, and maybe even long before that in China. In-situ leaching occurs prolifically in nature. When uncontrolled, it is called acid rock drainage.

In tropical environments, it is known that gold is sometimes leached from surface deposits in nature and is then redeposited below at an Eh or $\mathrm{pH}$ interface. Likewise copper is leached during the oxidation of porphyry deposits near the surface, transported in descending fluids and reprecipitated as a chalcocite blanket at the Eh boundary. Such processes, called "supergene enrichment" by geologists, are a natural form of in-situ leaching. Acid rock drainage is a form of natural in-situ leaching "gone wild". Preventing this natural form of in-situ leaching remains a formidable environmental challenge.

These natural forms of in-situ leaching take place over a time span of millions of years. Commercially interesting applications of in-situ leaching must provide a means of greatly accelerating the process and improving the recovery of metals.

\section{Sulfur}

The Frasch process produces sulfur through the injection of hot water into underground sulfur deposits as practiced in West Texas and offshore Louisiana. This was probably the first major commercial application of solution mining and has been a major source of sulfur for well over a century. Superheated water is forced down into underground deposits, melting the sulfur. Compressed air is introduced, and the less dense, liquid sulfur emulsion flows up through an outlet pipe to settling vats. Following cooling, very pure sulfur is produced in this way. This application falls more under solution mining and is less likely to benefit from the new concept described in this report.

\section{Salt}

Extraction of water-soluble salts (e.g., halite) has been employed to produce caverns in salt domes in Gulf Coast states. Although a related technology, this application is also unlikely to benefit from the new concept.

\section{Brine extraction}

Pumping of brines to the surface for extraction of valuable, naturally dissolved solids such as lithium, nitrates (Clayton Valley, Nevada and extensively in Chile), boron, and zinc (from geothermal brines near the Salton Sea, California) is also related technology but unlikely to benefit from the new ISL concept.

\section{Potash, trona, phosphate and nahcolite} nahcolite.

Solution mining is also employed in the production of potash, lithium, trona and

Hurd \& Fitch (1966) proposed that in-situ leaching of phosphate in the vast Bone Valley Formation in Florida would be possible using sulfuric acid as a lixiviant. Solution mining has also been employed for the recovery of potash in Western Australia, and Hancock (1988) refers to its potential application at several other locations around Australia. Solution mining has also been successfully applied in the production of trona $\left(\mathrm{Na}_{2} \mathrm{CO}_{3}\right)$ in the Wind River area of Wyoming. 
Solution mining is also employed to produce nahcolite, near Rifle, Colorado. The nahcolite deposits in Colorado occur in seams 1.5 to 6.1 meters ( $5 \mathrm{ft}$ to $20 \mathrm{ft}$ ) thick around 60 meters $(200 \mathrm{ft})$ below surface. There are lower grade lenses as well as high-grade veins, some with good continuity. Superheated water is injected to dissolve the nahcolite and the saturated solution is then pumped to the surface. American Soda, after several years of successful operation, was acquired by OCI, of Green River Wyoming, and the operation subsequently shut down. The American Soda project is described in an SME (2003) publication. At a separate project located nearby, the White River Group drilled two vertical wells that were then connected by horizontal drilling. Solution was then pumped down one vertical hole exiting from the other, leaching nahcolite en-route. This reputedly proved less efficient than hoped. None of these applications are likely to benefit from the new ISL concept.

\section{Uranium}

In-situ leaching accounts for around $16 \%$ of world uranium production according to the Uranium Information Centre (2001). It has become the primary producer of refined uranium in the United States, with a market share of $100 \%$ according to Pool (2002), up from around 95\% in the mid 1990's (U.S. DoE, 1999). This increase in the percentage of US uranium production appears more impressive than it really is because all conventional mining and milling of uranium came to a standstill when it became uneconomic during the mid- to late-1980's after a collapse in the price of uranium. ISL appears set to assume a new role also in Australia's uranium industry (Mudd, 2001a) where Southern Cross Uranium is developing the Honeymoon ISL project in South Australia.

In-situ leaching of uranium was first developed in the USA and the Soviet Union in the early 1960's. An unnamed Russian first suggested ISL mining of gold as early as 1896 (Mineev and Shutov, 1979, Morris, 1984 and Mudd, 2001b). Utah International acquired leases in the Shirley Basin of Wyoming in 1958 with a view to exploiting uranium deposits with a high strip ratio located under the water table in a large aquifer. Utah International also undertook confidential ISL experiments at Shirley Basin in 1961 leading to their patenting the ISL process. By 1962-63 Utah International was operating commercial scale ISL uranium production at Shirley Basin. By 1969-70, Utah International had fulfilled its AEC contract for 680,400 kg $(1,500,000 \mathrm{lbs}) \mathrm{U}_{3} \mathrm{O}_{8}$. The Shirley Basin ISL project employed sulfuric acid and oxygen as lixiviant.

After Utah International merged with GE in 1976, the uranium interests were spun off into Pathfinder Mines Corp. In the USA, in-situ leachable uranium deposits are typically measured in terms of grade thicknesses or GT, i.e. grade (in $\% \mathrm{U}_{3} \mathrm{O}_{8}$ ) $\mathrm{x}$ thickness (in feet). According to David Miller (2004, personal communication) ISL cutoff grades are typically at a $\mathrm{GT}=0.5$ to 0.6 . During the 1990 's average GT for producing operations was 1.2 , i.e. could be 6 $\mathrm{ft} \times 0.2 \% \mathrm{U}_{3} \mathrm{O}_{8}$ or $20 \mathrm{ft} \times 0.06 \% \mathrm{U}_{3} \mathrm{O}_{8}$. Typically uranium roll fronts of commercial interest range from 1.5 to 6.1 meters ( $5 \mathrm{ft}$ to $20 \mathrm{ft}$ ) in horizontal thickness, and 1.5 to 12.2 meters ( $5 \mathrm{ft}$ to $40 \mathrm{ft}$ ) in height. The mineralized roll fronts are typically stacked one on top of the other. In general, ISL of uranium works best at depths of 60 meters $(200 \mathrm{ft})$ or more as this results in higher oxygen concentrations due to the hydrostatic head of water as one goes deeper into the aquifer. The average grade at Shirley basin was in excess of $0.5 \% \mathrm{U}_{3} \mathrm{O}_{8}$. Roll fronts occurred with GT's in excess of 10 . The initial ISL operations produced in excess of the originally estimated uranium reserve of the area. Pathfinder Mines is believed then to have mined the 
leached areas by open pit mining and to have recovered the amount of the original reserve again by milling. This illustrates how difficult it is to estimate ISL uranium reserves and recoveries.

Pathfinder Mines in conjunction with Kerr McGee and Getty Oil in separate Shirley Basin projects are said collectively to have produced some 22.7 million $\mathrm{kg}$ (50 million $\mathrm{lbs}$ ) $\mathrm{U}_{3} \mathrm{O}_{8}$.

Other uranium producers were prevented from using ISL for uranium until Utah International's patent expired in the mid 1970's. In the late 1970's, Westinghouse's Wyoming Minerals developed the Irigaray uranium ISL project in the gas Hills of Wyoming. The Tennessee Valley Authority (TVA) was involved in ISL projects with Power Resources Inc. (PRI) a subsidiary of UK Nuclear Fuels. Urangesellschaft was also involved. Eventually Pathfinder Mines acquired TVA and PRI's interests, as well as that of Urangesellschaft, only itself to be acquired by Cameco. All uranium ISL projects in Wyoming after the mid 1970's used sodium carbonate or ammonium carbonate with oxygen as the lixiviant. The Wyoming ISL projects operated at depths of around 91 to 183 meters (300 ft to $600 \mathrm{ft}$ ) below surface.

Rio Algom, then a subsidiary of Rio Tinto, developed the Smith Ranch ISL project near Crawford, Nebraska at a depth of 183 meters to 366 meters $(600 \mathrm{ft}$ to $1,200 \mathrm{ft})$ below surface. Following BHP's acquisition of Rio Algom, the Smith Ranch ISL operation was sold to Cameco.

Several companies, including US Steel, Mobil Oil, Federal American Partners and Uranium Resources Inc, developed significant uranium in-situ leaching projects in south Texas. These deposits were also sandstone hosted and were located beneath the water table in isolatable aquifers.

Mobil Oil tested in-situ leaching of uranium at its Crown Point project in New Mexico. There were two sandstone horizons (one 61 meters thick or $200 \mathrm{ft}$ thick) located at a depth of 549 meters $(1,800 \mathrm{ft})$ below the surface. The uranium solutions from Crown Point were exceptionally "clean" but with molybdenum byproduct. Phillips Uranium, a subsidiary of Phillips Petroleum, tested in-situ leaching at the Nose Rock uranium deposit also in New Mexico in the 1980's. Molybdenum leached with the uranium and constituted a potential by-product. The project did not proceed to commercial operation when the uranium market imploded soon thereafter.

During the late 1980's uranium was also successfully recovered by in-situ leaching from mine tailings impoundments at the depleted Fall City uranium mine site.

With in-situ leaching, low-grade uranium deposits (approximately $0.1 \% \mathrm{U}_{3} \mathrm{O}_{8}$ ) can be mined. These grades are considerably lower than can be mined by conventional means, especially compared with typical grades in the unconformity-type deposits currently mined in Saskatchewan, with grades of the order of $4 \%$ to $10 \% \mathrm{U}_{3} \mathrm{O}_{8}$ and even as high as $20 \% \mathrm{U}_{3} \mathrm{O}_{8}$.

Also in the late 1980's waters pumped from underground uranium mines were found to carry uranium. Several fluid-bed ion exchange plants were installed in New Mexico to recover uranium from this water. This was a form of in-situ leaching, again involuntary. When uranium was found to be leaching into underground mine water at a Denison Mines operation near Elliott Lake, Ontario, the process was deliberately enhanced resulting in the recovery of considerable tonnages of salable uranium yellowcake. Acidic mine water was sprayed onto mined out stopes. Additional in-place leaching extracted uranium from blasted, rubblized ore as described by McCready and Gould (1990). The Elliott Lake ores consist of quartz pebble conglomerates with some pyrite in the matrix. Bio-oxidation of the pyrite generates the acid and ferric ions needed to leach the uranium.

It is recognized that the new technology described in this white paper will not be universally applicable for in-situ leaching, but will apply initially to deposits that conform to a somewhat specific geometry and depth below surface. Conventional ISL works very well for 
uranium roll front deposits hosted in porous sandstone. There would generally be little incentive to apply the new ISL concept to the type of deposits known to occur in Nebraska, Texas and Wyoming, other than those located above the water table.

To date, in-situ leaching of uranium in porous sandstone deposits has been developed solely to exploit deposits that lie within an aquifer, i.e. below the water table. Several sandstone deposits of uranium are also believed to exist above the water table. It remains to develop the ISL concept described herein to be possibly applicable also to such deposits. Permitting the exploitation of such deposits is likely to be a challenge.

It is also possible that the new ISL concept developed in this white paper may be applicable for the exploitation of breccia pipe deposits containing uranium such as are known to occur near the Colorado-Arizona border. Bio-oxidation of sulfide minerals in these deposits may provide a handy means of generating the lixiviant in-situ.

\section{Copper}

Steve Axen of Ray Huff and Associates, Golden (2004 personal communication), a veteran in-situ leach proponent and engineer, believes that ISL is ideally suited to exploit oxide copper deposits that are too small, too low-grade or too deep for conventional mining.

Thus far, only two commercial currently operating ISL copper recovery operations have been identified in North America, namely the rubble leaching operation at ASARCO's Silver Bell copper mine located NW of Tucson, AZ and in-situ leaching of mined out stopes at BHP's San Manuel copper mine, also in Arizona. Both of these successful in-situ leach demonstrations, however, involved previously mined sites as opposed to virgin ore deposits. The National Academy of Sciences (2002), Bartlett (1992, 1998), Coyne and Hiskey (1989), Schlitt and Hiskey (1981) and Schlitt and Shock (1979) considered these to be successful in-situ leach demonstrations and concluded that in-situ leaching of copper requires a means of creating sufficient permeability for lixiviants to contact ore minerals.

At its Silver Bell operations, ASARCO fractured a body of low-grade oxide ore adjoining a mined-out open pit, creating permeability for leaching with sulfuric acid. Pregnant leach solution collects in a pond at the bottom of the pit from where it is pumped to the solvent extraction (SX) plant for copper extraction. Bob Washnock (2004, personal communication), former VP metallurgical operations at ASARCO Silver Bell, estimates that the in-place leaching of rubblized rock at Silver Bell achieved a recovery of perhaps $20 \%$ to $25 \%$ of the contained copper. The relatively low recovery is probably the result mainly of inadequate contact between leach solution and the ore minerals and poor oxygenation. Recovery of copper from material in this type of environment could potentially be improved by the new ISL concept described here.

Bob Washnock is now developing the Lisbon Valley copper heap leach project in Utah, belonging to Constellation Copper. Lisbon Valley mineralization is sandstone-hosted. Ore is located in an upper aquifer that will be dewatered around the open pit mine with a strip ratio around 2.2 tonnes waste to 1 tonne ore. The upper aquifer is separated from an underlying aquifer by 152 meters $(500 \mathrm{ft})$ of shale that would be expected to protect water quality below. It is possible that there are satellite ore zones that can be evaluated for amenability to in-situ leaching in the future. However, this possibility is not a current focus as the flat lying copper ore deposits are spread out and may not be continuous. Copper occurs in oxide minerals as well as the secondary sulfide chalcocite. 
Near surface disseminated copper porphyry deposits, and potentially also disseminated gold deposits, e.g. gold porphyries appear to offer the best potential for application of the new ISL concept.

Magma Copper in the 1990's carried also out a significant demonstration ISL copper leaching and recovery operation at Florence, AZ employing sulfuric acid. Florence is a porphyry copper deposit believed to be located at around 518 to 610 meters $(1,700 \mathrm{ft}$ to $2,000 \mathrm{ft})$ depth. Other observers estimated that the tests demonstrated, it is reputed, good permeability and connectivity between wells. Some US\$ 20 to 30 million was spent on this leach test. Following the acquisition of Magma by BHP, however, the leach test was cut short followed by extensive reclamation pumping and water treatment to restore the aquifer. This is believed to have been successful. In 2002 the project was listed for sale along with other BHP assets and it was hoped to see it reactivated on a commercial scale. At least one mining company is believed to have been seriously interested when copper prices escalated to over US $\$ 1.25 / 1 \mathrm{~b}$ in 2004 . However, the property was sold to a real estate developer, and can now never be developed for ISL. It is unfortunate that after all the effort and investment that went into Florence, the results of the reputedly successful "hard rock" in-situ project have not been made available to those interested in advancing the science.

ASARCO, in partnership with the US Bureau of Mines, undertook an in-situ leaching test at Casa Grande, AZ. The ore deposit, like Florence, was a copper porphyry with similar mineralogy, only at a depth of around 914 meters (3,000 ft). The well-documented Casa Grande ISL project, however, yielded very little copper. Observers believe this was because porosity of the porphyry was poor, possibly on account of its depth. The Casa Grande ISL project is well documented in publicly available USBM reports published during the 1990's and probably also in papers published at conferences.

Magma Copper Company, (subsequently acquired by BHP) recovered copper from solutions applied to mined out stopes at San Manuel, Arizona. The oxide cap at the surface was to a large extent removed by open pit mining. It was underlain by a zone of mixed oxide and sulfide mineralization with chalcocite mineralization, grading to primary sulfide ore at depth. Some degree of ground movement occurred and there is reported to have been some subsidence. Towards the end, underlying sulfides were mined at depth. Later, leach solutions were injected into the transition zone, and residual ore was rubblized into the open stopes. About $50 \%$ of the ISL copper produced at San Manuel was recovered from solutions collected from the stopes below, the remainder from solution recovery wells. Due to ground movement, the earlier drill hole assays were no longer valid after 45 years of mining. Consequently, copper recovery was very hard to estimate with any accuracy. Therefore, the 50-60\% copper recovery figure mentioned by The National Academy of Sciences Committee (2002) is likely to be unreliable. The stopes were located within an aquifer, and solutions flowed inwards to replace solutions pumped to the surface. Rock permeability outside the stopes was higher than that of the rubblized and open areas than within the stopes. Monitor wells placed around the perimeter indicated no sign of leakage. Industry observers are comfortable that the ISL project at San Manuel was environmentally sound.

Ranchers Exploration in 1972 set off 1.8 million $\mathrm{kg}$ (4 million pounds) of ammonium nitrate/fuel oil (AN/FO) to blast 6 million tonnes of copper ore on the side of a hill for in-place leaching at the "Old Reliable" project, located $75 \mathrm{~km}$ (45 miles) NNE of Tucson. At that time it was the largest conventional explosives blast in history. Following fracturing, sulfuric acid lixiviant was applied and copper was leached and recovered. The project has been described by 
Scheffell (2004, personal communication) as "an economic success but a technical failure". Apparently the oxide copper leached well, but copper occurring as the sulfide mineral chalcocite did not leach. This led Scheffell (2004, personal communication) to believe that chalcocite could not be leached in-situ or on heaps, which of course is known today not to be the case. It is probable that chalcocite failed to leach due to inadequate oxidant being present in the fractured rock. An abandoned mine drift into the side of the hill at the water table provided a means of collecting pregnant leach solution. To this day a trickle of ARD is believed to flow from the adit, and the site has been the subject, reputedly, of litigation. Here is an example of a project that could well have benefited from the new ISL concept described in this white paper. Improved oxygenation and the constantly changing flow pattern of solutions would likely have improved leach recovery. The ability to inject air or oxygen into the leaching column of fragmented rock would likely have leached copper from the chalcocite too.

Ranchers Exploration "blew" low-grade oxide copper bearing material into the pit at a worked out copper mine near Winnemucca, NV. The fractured rock was then leached in-place. Submersible pumps in the pit bottom brought pregnant leach solution to the surface for copper recovery.

Copper, according to Stano (2004, personal communication) occurs in porous sandstone deposits at the Naciomientos property in Cuba at depths of 30 to 46 meters (100 ft to $150 \mathrm{ft}$ ) within a water table. A pilot ISL test consisting of ten wells was performed there reputedly during the 1990s in virgin ground, not impacted by earlier mining operations. Copper leached well and was produced in solutions from which copper was recovered by cementation. The ore contained some carbonates that consumed sulfuric acid lixiviant. Stano (2004, personal communication) recalls that the reagent dosing and consumption needed "trimming", but that the under-funded test project was regarded to have been a technical success. The copper grade is irregular, but averages around $0.3 \% \mathrm{Cu}$. The near surface oxide deposit is underlain by sulfides containing up to $0.5 \%$ to $1.0 \% \mathrm{Cu}$ with silver values that had been mined previously. Flotation concentrates were produced at some time in history at an old National Lead Company pit which remains on the property. The Naciomientos copper deposit, hosted in a porous sandstone environment within an aquifer, may possibly be more amenable to the uranium ISL approach than the new ISL concept presented in this white paper, but this has yet to be established.

Occidental Minerals, a Division of Occidental Petroleum, in the 1970's and early 1980's carried out an in-situ leaching project to extract copper from oxide ores at Miami, Arizona. This in-situ leaching project operated for 5 to 7 years and closed down in 1982 when Occidental Petroleum got out of the minerals business.

Metall Mining, a predecessor of INMET Mining, carried out large scale in-place copper leaching demonstration activities in an underground copper mine in Michigan but the degree of success achieved is not widely known, nor is the degree to which the site could be reclaimed on completion.

During the 1970's, Kennecott Copper undertook in-situ leaching tests in a deep copper porphyry deposit near Safford, Arizona. Wayne Henderson, a pioneer in in-situ leaching, relates that in-situ leaching was tested on porphyry ore that had been hydro-fractured as well as explosively fractured. Apparently Kennecott invested around \$20 million in these tests that operated for some three years or so. In current dollars that would be a very significant commitment. The in-situ leach test was carried out at a depth of around 762 meters $(2,500 \mathrm{ft})$ below surface in a porphyry deposit located close to leases owned by Phelps Dodge in the Safford area. Wayne recalls the name "East Man Deposit". He believes that Phelps Dodge 
ultimately acquired the property. Acid proofed submersible pumps with titanium impellers and 1500 psi pressure capability were used. Key to success in extracting copper from this chalcopyrite deposit was the ability to make an emulsion of very small pure oxygen bubbles in solution that created a powerful oxidant under the significant hydrostatic head. The porphyry ore tended to be fractured and there were challenges in avoiding fugitive loss of solutions. Ray Huff of Colorado was involved in this interesting project about which little appears to have been published.

Huff and Associates completed a successful in-situ leaching project test at Chuquiquamata, Chile at CODELCO's Mina Sur copper deposit. The mineralization consists of 100 percent exotic oxide copper mineralization cementing together alluvial gravels in a tilted paleo channel. The field test achieved good permeability of the copper bearing formation and was able to recover copper bearing pregnant solutions.

ISL trials were carried out at several sites near Mt. Isa, Queensland in the late 1960's and 1970's according to Bell (1984) and Mudd (2001a). More recently, a variant of stope leaching was tested at the Gunpowder (Mammoth) copper mine also in Queensland (Landmark, 1992; Middlin and Meka, 1993; Mudd, 2001a). A small experimental acid ISL copper project was conducted at the old Mutooroo mine, $100 \mathrm{~km}$ south of Honeymoon, South Australia during 19811982 according to Bampton et al. (1983). On a 2001 trip to Australia, von Michaelis (2004 personal communication) learned from Electrometals Technologies Ltd. that EMEW (Electrometals electrowinning) cells had been used on a small commercial basis for copper recovery from a small in-situ leach operation in Queensland during the late 1990's.

In-situ bioleaching of copper was pilot tested at San Valentino di Predoi mine in northern Italy according to Rossi et al. (1986). Important ore minerals were pyrite, chalcopyrite and pyrrhotite. The mine closed in 1972. This was not a true "in-situ" bioleaching application. Rather, "in place" bioleaching had begun on 10,000 tonnes of $<0.5 \%$ copper waste backfill and low-grade ore that had been stored underground. Copper was collected by cementation. Little data was given as the test had just begun at the time the paper was written. The unmined part of the lens contained at least 40,000 tonnes grading $1 \%$ to $2 \%$ copper. The plan was to expand the operation to the unmined ore by fracturing it with explosives. It remains to be determined whether this was implemented and the results obtained.

Numerous large copper heap leaching operations have been successfully brought into production since the 1980's particularly in Chile, the USA, Mexico and Peru. Some of these operations treat oxide ores, whereas several others treat chalcocite ores. These heap leaching successes are relevant to this white paper on in-situ leaching, because much of the same leach chemistry that has been successfully applied in heap leaching, would become directly applicable to in-situ leaching where the new concept described in this white paper finds application.

Increasingly, bioheap leaching processes are being applied for the extraction of copper from sulfide ores. Brierley \& Brierley (2000) summarized the operational parameters and techniques involved. They concluded: "Copper bioheap leaching is considered an important processing tool by the mining industry because of its low costs, short construction times, operational simplicity, good performance, and environmental advantages." The innovation that is the focus of this white paper promises to extend the applicability of bioleaching to ore deposits that are not economically viable for mining by conventional techniques.

Noranda conducted tests and took a copper bioleaching project to feasibility at the Geco mine in Ontario. According to Ismay et al. (1986), a reserve of 2.5 million tonnes of low grade $(0.5 \%)$ massive sulfide copper bearing rock was developed. Access to this ore deposit was from 
an adjacent underground mine area. It was concluded that lower cost methods of fragmenting the ore in place would be required before this project could be deemed economically viable.

The technology focus of this white paper is aimed at leaching bulk base metal ore deposits such as copper porphyries and breccias, volcanogenic and sediment hosted massive sulfides. It is likely that these will respond to acid leaching systems and unlikely that they will respond to alkaline leach chemistry. Therefore this report focuses on the less well-known ISL work using sulfuric acid to recover copper, nickel, and zinc from ores containing oxide and sulfide minerals. Bio-oxidation technologies for base metal sulfides are all based upon sulfuric acid leaching systems. A benefit is that the oxidation of sulfide minerals produces sulfuric acid for use as a reagent, as well as liberating the valuable metal ions.

\section{Gold}

During the late 1980's water pumped from underground workings of a gold mine in the Northwest Territories, Canada was found to contain low levels of gold. Seepage of very weak cyanide solution from the overlying tailings impoundment had found its way into the mine workings and resulted in leaching of some gold. The water was pumped from underground and used as process water in the mill resulting in incremental gold recovery. So, the first known commercial in-situ leach of gold was involuntary.

The western world's first deliberate in-situ gold mine was proposed at Eastville, central Victoria in the early 1980's by CRA Ltd. as described by Bell (1984) and Hore-Lacy (1982). The project planned to inject alkaline cyanide into the "deep leads", an underground porous paleoalluvial formation. von Michaelis (personal communication, 2004) discussed this and other potential in-situ leach gold projects at length with the CRA project manager at that time. The insitu leaching project in principle was viable and unlikely to result in any damage to the aquifer as long as production pumping exceeded injection volumes. The deep leads lie beneath grazing lands in Victoria. Both the community and regulators expressed concerns about the possibility of groundwater contamination arising from the use of cyanide in the rural farming area. After some initial pump and dye tracer tests (Hore-Lacy, 1982), regulatory approvals were denied and CRA later abandoned the project. The new concept described herein incorporates a unique solution collection system that virtually eliminates the potential for ground water contamination. CRA or BHP subsequently also evaluated an in-situ gold leaching project in Western Australia, but it is believed that it never advanced to a full-scale test.

More recent advances in gold leaching using thiosulfate, hypochlorite, or acidified chlorine solutions may possibly provide a future means of exploiting gold production from the deep leads avoiding the concern that arises anytime anyone proposes to pump cyanide into an aquifer. Huff and Associates developed and patented a chlorine dioxide-chloride lixiviant for gold that is effective in the $\mathrm{pH}$ range 6 to 7.

The configuration of the deep leads gold occurrences would probably not be suitable for application of the new ISL concept that is reviewed in this white paper. The deep leads are buried deeply and they also do not have adequate thickness to benefit from the new concept. Porosity and configuration of the deep leads gold deposits makes conventional ISL more applicable. 


\section{BENEFITS OF IN-SITU LEACHING}

The benefits of in-situ leaching are summarized as follows:

- Applicability: In-situ leaching may be applied to lower grade ores and/or smaller ore deposits where conventional mining is uneconomic.

- Aesthetics and land use: Smaller footprint of the operation, i.e. absence of waste disposal sites, large open pits, and huge ore processing facilities.

- Energy efficiency: Much less energy is required for in-situ leaching than other forms of mining.

- Efficient use of water: In-situ leaching can reduce water consumption compared with conventional mining as a result of reduced evaporation and elimination of water content in conventional tailings.

- Process conditions: When it is possible to apply solutions under a hydrostatic head, leach rates may be enhanced due to, for example, enhanced oxygen concentration in solution.

- Hydrometallurgy: In-situ leaching employs hydrometallurgy which offers several advantages over older pyrometallurgical processes (e.g. smelting). In-situ leached metals are mostly recovered from pregnant leach solutions by processes such as ion exchange, cementation, and electrowinning.

- Economic: Avoiding the need to mine, handle, crush, grind, treat and transport large quantities of ore, waste and concentrate potentially improves the economics of metal production.

- Environmental: Elimination of huge open pits, ore and waste stockpiles of conventional mining and mineral processing. Better control of acid rock drainage may be possible (however, great care needs to be taken to protect water quality in aquifers that may potentially be impacted by ISL).

- Dust control: Almost total elimination of dust emissions.

- Reclamation: In-situ leaching projects should be faster and less costly to reclaim on completion of the operation. This benefit must still be proven in practice. 


\section{SHORTCOMINGS \& DISADVANTAGES OF IN-SITU LEACHING}

The shortcomings and disadvantages of in-situ leaching are summarized as follows:

- Lower recoveries: In general, leach solutions contact only limited parts of the ore, resulting in lower recoveries particularly for hard rock copper and gold deposits. The new concept described herein improves this. In-situ leaching of uranium roll front deposits in porous sandstones yield relatively good leach recoveries

- Loss of fugitive leach solutions can result in environmental damage, reduce metal recovery and result in loss of valuable reagents. The new concept described herein virtually eliminates the potential for solution loss.

- Hydrology: Solution flow patterns through ore deposits have been hard, if not impossible, to accurately quantify, engineer and control. The new concept described herein provides a means of continually changing the flow patterns, thereby ensuring better solution contact.

- Leach Time: In-situ leaching may require more time for metal extraction than conventional mining and processing. The new concept described herein can be economically operated for a long period of time and also improves the metal leaching rate.

- Water table: Generally in-situ leaching works best when pregnant leach solution can be collected beneath the water table. Not every leachable deposit is located conveniently within an aquifer or close to a water table. The new concept described herein may be applied above and below the water table, but this needs to be proven.

- Environmental management of in-situ leaching for uranium in sandstones works best when the ore body is hosted in a separate aquifer that can be sealed off from adjacent aquifers above and below.

- Working in the dark: in-situ leaching technology relies on hydrology models and predictions. It is generally impossible to observe what is really occurring below the earth's surface. The new technology will, however, make it possible to obtain a better picture of the process.

- When in-situ leaching ores above the water table, there may be a requirement to create engineered barriers to contain leach solutions within the ore deposit (Batterham, 2004). This is important for both environmental protection and for recovery of metal values and lixiviant. The new concept described herein utilizes a collection system wherein fugitive solution loss should not occur as flows will be into the reaction vessel. 
- In-situ projects using sulfuric acid have yet to be proven to be environmentally sound. Most successfully reclaimed in-situ leach projects to date have been for uranium in sandstone hosted roll front deposits. Most of these have employed sodium carbonate and oxygen (or peroxide) as lixiviant. These are believed to be easier and less costly to reclaim than in-situ leach projects employing sulfuric acid. Sulfuric acid in-situ uranium leach projects have a poor track record in Eastern Europe and Russia. This came about primarily because adequate safeguards were not designed into the projects in the first place, and sulfuric acid leaching should not by any means be ruled out. 


\section{GENERAL DESCRIPTION OF IN-SITU LEACHING AND INTEGRATION OF THE NEW CONCEPT WITH CHEMICAL AND BIOLOGICAL EXTRACTION}

Leaching is defined as the extraction of minerals or metals by dissolving them selectively from the solid matrix of the ore. In-situ leaching, as a distinct mining method, may be defined as the extraction and recovery of mineral values by dissolving them directly from in-place ore deposits (Liu and Brady, 1998).

In-situ leaching technologies are based on geology, geochemistry, solution chemistry, process engineering, chemical engineering, hydrology, rock mechanics, explosives technology rubblization, and petroleum engineering (Wadsworth, 1983).

The leaching process results from the flow of a reactive fluid (the lixiviant) through a permeable geological medium (Mulhaus et al., 1999). Leach solutions containing reagents (typically sodium carbonate, ammonium carbonate or sulfuric acid with additional oxidant such as oxygen gas, hydrogen peroxide, sodium peroxide or nitric acid) in the desired concentrations are typically injected into a permeable ore deposit in such a way that valuable components, e.g. copper, gold or uranium are brought into solution. The pregnant leach solution (PLS) is then collected and pumped to the surface where it is processed to recover the valuable metal or other mineral product(s), before the leach solutions are fortified through addition of reagents and reinjected into the ore deposit.

In-situ leaching can broadly be grouped in five types:

- Injection of lixiviants into porous sandstone to leach disseminated uranium

- Injection of fluids into subterranean caverns to dissolve or melt non-metallic minerals, e.g. Frasch sulfur, trona, nahcolite, potash, etc.

- Leaching of metals, e.g. uranium, copper, nickel, etc., in underground stopes assisted by biooxidation of sulfides.

- Rubble leaching of blasted sidewalls of open pits

- Leaching non-porous ore fragmented by blasting with or without biooxidation assist.

This white paper focuses particularly on the last of these five types of in-situ leaching. This is the application that has seen the least commercial applications to date.

To be successful, in-situ leaching requires a practical operating system. It is essential to adopt a systems approach that integrates all the components. For example, successful leaching may require proper ore fragmentation, solution distribution system, solution addition rate and distribution control, reagent addition systems, $\mathrm{pH}$ control, dissolved oxygen or other Eh control, air injection system, biooxidation nutrient addition and control, a means of progressively monitoring leach recovery, pregnant leach solution collection system, metal recovery system, product packaging and shipping system, an appropriate means of preventing or limiting solution excursions and losses, a monitor well system, environmental reporting system, an effective ongoing reclamation system, etc.

In-situ leaching operations may comprise six main components:

a) Physical aspects 

b) Leach chemistry
c) Solution injection and recovery system
d) Bioleaching of metals
e) Metal recovery system
f) Environmental management and reclamation

These six operations are discussed more fully below.

\section{a) Physical Aspects of In-situ Leaching}

Two different approaches appear to be required depending on whether the ore deposit is porous or non-porous, i.e. not adequately porous for solutions to permeate at an adequate rate to access metal values.

For effective in-situ leaching it is important that the ore body be adequately permeable, and that channeling of leach solutions be minimized within the ore zone. Unwanted plugging of lixiviant flow patterns needs also to be prevented.

Physical aspects account for two major problems that need to be solved before in-situ leaching can be applied on a widespread basis:

1) Adequate lixiviant solution contact with the minerals containing the metal values is essential for efficient metal leach recovery. Adequate fracturing and prevention of plugging are key aspects.

2) A means must be found to contain leach solutions to the ore body (Batterham, 2004). This is essential for environmental protection, product recovery and lixiviant reagent conservation.

\section{Permeability and Porosity}

A National Academy of Sciences Foundation Committee on Evolutionary and Revolutionary Technologies for Mining, chaired by Milton Ward, a leader in the copper mining industry, issued a report (2002) that states: "The chief hurdle to using in-situ leaching for mining more types of mineral deposits is permeability of the ore," and later: "New technologies for the in-situ fracturing or rubblization of rocks could be extremely beneficial." Technologies that could fracture and rubblize ore in such a way that fluids would preferentially flow through the orebody and dissolve ore-bearing minerals (although this would be difficult in competent rocks with high compressive strengths) is, therefore, a high priority need for in-situ mining.

The report compiled a list of Opportunities for Research and Technology Development in In-Situ Mining. It includes the item: "New mining technologies for increasing permeability for in-situ leaching, particularly of base metals."

It stands to reason that unless the leach solution can be brought into intimate contact with the valuable mineral particles within the ore, the valuable components will not be leached efficiently.

It is important to learn and understand the distinction between permeability and porosity of the rock and the formation to be leached. Porosity is inherent in the rock and is not really enhanced by rubblization, rather distribution of solution is enhanced so that solutions need to 
travel shorter distances into the mineral bearing rock in order to gain access to the minerals to be leached. Hydrofraccing has a similar effect. Formation permeability can be reduced as a result of the migration of fines. The new concept described in this white paper provides a means of improving distribution of lixiviant throughout the ore column, i.e., making the ore formation more permeable to lixiviant solutions.

Porosity of an ore can be improved by leaching out sulfides and leaving voids, but can be reduced by precipitation of jarosite and/or reactions with gangue such as gypsum precipitation.

In-situ leaching is currently limited to low-grade deposits in highly permeable (hundreds to thousands of millidarcies), essentially horizontal sandstones, such as uranium in porous sandstone deposits such as occur in Wyoming and Texas. Attempts have been made in the past to design in-situ leaching wellfields in formations with just a few millidarcies permeability, but none is known to have been commercially successful.

Transfer of mass from solid to solution is a consequence of simultaneous processes such as advection, diffusion, dispersion, and sorption (Liu and Brady, 1998). Macro distribution of solution through the ore mass is as important as migration of solution into and out of discrete ore fragments on a micro scale.

When leaching uranium in porous sandstone deposits, the challenge is to ensure that the leach solution comes into contact with the mineralization. The mechanism by which the mineralization was precipitated from solution in the pores of the formation, inherently implies reduction of porosity. Fracturing that type of ore may be counter-productive.

For the in-situ leaching of more "massive" gold, silver, copper and nickel ores with low porosity, the challenge is to get solutions to permeate through "solid" rock. Here, fracturing of the ore may be essential for success. Several approaches to fracturing rock underground have been proposed. Some of the ideas are summarized below and in the section on "Patents". None have thus far found successful application in commercial practice because none was able, in practice, to achieve adequately uniform fineness of fragmentation. This is likely due to inadequate void space to accommodate the swell factor.

The National Academy of Sciences Foundation Committee report (2002) concluded: "Although lixiviants are available to leach various copper oxide and copper sulfide minerals, attempts at in-situ leaching of copper in pristine formations have not been very successful because the lixiviants have not been able to adequately contact the ore minerals in the rock". The most successful in-situ copper leaching has been in ore bodies that had been previously mined; after the high-grade ores were removed open stopes remained with rubble of lower grade wall rock that could be contacted by lixiviants. New technologies for the in-situ fracturing or rubblization of rocks could be extremely beneficial. Increasing permeability in the rocks to allow lixiviants to contact ore minerals is the biggest challenge for the in-situ leaching of metals. One promising approach to increasing permeability, as has been done for copper, is to rubblize rock using conventional mining techniques, thereby taking advantage of the open spaces created to achieve better distribution of lixiviant solution through the mineralized mass.

It is precisely this need that the new ISL concept presented in this white paper seeks to address--rubblization of ore in-situ--but in virgin deposits, and in an engineered manner. The new technology goes further, by introducing the means to further improve contact between ore, injected and dissolved air, and lixiviant. In principle, recoveries should be better than can be achieved in any run-of-mine heap leach operations. 


\section{Rubblization and Solution Wetting}

Girard \& Hart (1974) proposed setting off a nuclear blast underground to create 'nuclear chimneys' to collect pregnant leach solutions introduced through injection wells into the surrounding rock.

Jacoby (1974) advocated drilling two bore holes to the base of the deposit followed by hydraulic fracturing of the formation to create a 'base fracture zone' to interconnect the lower ends of the boreholes. Explosives could then be pumped into the base of the deposit and, it was proposed, detonated to fracture the overlying ore body.

Simply drilling into a deep (30 to 914 meters or $100 \mathrm{ft}$ to 3,000 ft) underground ore body and blasting will create fractures, but leaves large unbroken fragments between the fractured zones. Some of the fractures will be closed or plugged with fines. Coursen (1976) proposed a "blast-flush" process to improve permeability. In this invention, explosive charges are detonated sequentially in separate cavities in the ore body producing a cluster of overlapping fracture zones. Each detonation takes place after liquid has entered the fracture zones produced by the previous detonations. Permeability could be maintained by flushing the fractured rock with liquid to remove fines.

Jones and Greene (1986) proposed a process designed to introduce parallel fractures in ore deposits of low permeability. After hydraulically fracturing a well bore, the principal fracture direction is determined and is used to position production wells to collect leach solutions along the lines of the induced fracturing.

Graves (1985) proposed the creation of a 'pancake' or horizontally oriented fracture pattern in the upper zone of an ore body. The fracture pattern is connected to the injection well drilled into the ore body. "Proppants" are introduced to keep the fractures open as is done in oil fields. Then leach solutions are introduced that flow first horizontally and then vertically to recovery wells drilled deep into the periphery of the ore body.

Considerable technology has been developed in the uranium in-situ leach (ISL) industry for bringing solutions into contact with uranium that has become concentrated in porous sandstone hosted ores, and then for collecting pregnant leach solutions (PLS) containing uranium. The famous "five spot" patterns employing four solution injection wells positioned around each extraction well have typically been employed in uranium ISL projects in Wyoming, Nebraska, Texas and elsewhere. Typically there is an average of 1.0 to 1.3 injection wells for each production well in the overall wellfield.

Successful uranium ISL leaches uranium in porous sandstone ores located in aquifers, i.e. below the water table. Although there are successful rubble leaching operations (e.g. for copper at Silver Bell copper mine, Arizona) in which ore is leached in an unsaturated mode, ISL experts point out that they have yet to come across a successful ISL operation where solution is applied to "dry" ore. There are variations in opinion with respect to the best way to leach uranium in porous sandstone ores. David Miller of Strathmore Minerals in Riverton, Wyoming points out that it is best when leach solutions are injected on the reducing side of the sickle shaped uranium roll front, and collected on the oxidized side of the roll front, thereby forcing solutions to flow through the roll front where uranium is concentrated and avoiding re-precipitation of uranium once leached as would be the case if solutions again contacted the reducing zone.

The design of the leach field as well as the rate of solution injection into the ore is a function of hydraulic models that have been developed over several decades of trial and error, as well as being based on engineering principles. Huff and Associates suggests that rather than 
attempting to modify the permeability of an ore, a better approach is to design the well field to cater to the ore characteristics and to "live with" its permeability.

In-situ leach operators advise that in practice in-situ leaching does not always follow as models would predict. Apparently there is as much art as science and one optimizes the performance of an in-situ leaching operation by learning empirically from previous results on that particular project.

Solutions that permeate through ore in an underground ore deposit logically follow the path of least resistance. If there are open fractures in the ore, solution will most likely find its way along the fractures thereby reducing the degree of contact with the ore, except at the fracture surfaces. Even if the ore is blasted to enhance fracturing before solution is applied, solution flow will follow patterns dictated by the physical nature of the fractures. Some ore particles will be exposed to solution, whereas other parts of the ore may be left unleached because no lixiviant solutions reached that zone. As a result leaching can be far from uniform through the mass of the ore.

Although the above patents outline several possible methods to fracture ore bodies, none provides a means of generating a widely and uniformly distributed pattern of interconnected fractures likely to bring extensive leach solution contact with the ore. None of the above makes adequate provision for the "swell" in the ore deposit brought about by introduction of widely disseminated void spaces and fracture openings. The new concept described in this white paper provides such a system.

This white paper describes a new technology designed to optimize contact between ore and leach solution thereby making it possible to improve overall leach recoveries. The new ISL system is novel in that it proposes ISL of less permeable ores that can be above or below the water table.

Typically around $95 \%$ to $99 \%$ of the matrix remains physically unchanged after ISL. In the new ISL system proposed here ore is fragmented by blasting in-situ, and solution then applied to the top of the column of fragmented ore and pumped from collection points located below the column of ore. A major difference between conventional ISL and the new system described in this white paper is that the flow patterns of solution percolating through the column of in-situ fragmented ore are deliberately modified on a regular basis to ensure that all ore fragments become "wetted".

\section{Containment of Solutions}

The National Academy of the Sciences (2002) report states: "Confinement of lixiviants and mobilized metals to the mining area is another major challenge."

Unless the "pregnant" leach solution (PLS) can be collected with minimum fugitive losses, and pumped to the surface for recovery of the economically valuable components, the efficiency of metal recovery will be adversely impacted. An efficient means of recovering the pregnant leach solution after contact with the ore is therefore equally important to bringing the leach solution in contact with the ore in the first place.

Recovery of leach solutions was a challenge at Kennecott Copper Company's deep high pressure in-situ leach project near Safford, AZ in the early to mid-1970's. Solutions, it is believed, tended to escape along fracture zones in the ore. 
Hydraulic models for in-situ leaching must be site specific in nature since the hydrology within each ore deposit is different. The innovative technology described in this white paper provides a means of controlling the hydrology of a deposit that is undergoing in-situ leaching.

Attempts to in-situ leach residual gold left in underground gold mining stopes on the Witwatersrand failed on account of being unable to adequately recover solutions after they had been brought in contact with gold particles that had migrated deep into fractures in the mine footwall during the mining process. In this case finely divided free gold was located in fractures in the footwall.

During the 1990's several experiments were carried out with a view to in-situ leach gold located in microfractures in the footwall of Witwatersrand gold mines in South Africa. In particular, Thiotek Inc. tested various leaching approaches at West Driefontein Gold Mine. MINTEK carried out tests along similar lines. Unfortunately, although gold leached, solutions escaped through cracks and no effective way could be found to efficiently collect the pregnant leach solutions. Ammonium thiosulphate lixiviants were tested (use of cyanide was not considered wise in an operating mine with low $\mathrm{pH}$ waters) and discontinued due to miners at different levels, reputedly complaining about the odor of ammonia in their work environment.

\section{b) In-situ Leach Chemistry and Lixiviants}

The National Academy of the Sciences (2002) report: "Lixiviants are available for leaching not only uranium and copper, but also gold, lead, and manganese, to name a few. Nevertheless, cheaper, faster reacting lixiviants would increase production and could also increase the number of metals that could be considered for in-situ leaching. At the same time, lixiviants need to suppress the dissolution of undesirable elements, such as arsenic and selenium, which have geochemistries that are significantly different to uranium, would be helpful, as would additives that lower concentrations of those elements during reclamation."

The lixiviant reagent should ideally be selective in its leaching of a specific metal in a given ore body. The mass transfer from solid to solution is the result of simultaneous processes such as advection, diffusion, dispersion and sorption (Liu and Brady, 1998). This white paper considers leaching agents from two perspectives: 1) chemical leaching, and 2) biological leaching. The innovative physical approach to in-situ leaching that forms the prime focus of this white paper provides a realistic way to enhance leach conditions.

In addition to lixiviants, oxidants are often required, typically oxygen, peroxide, ferric ions, chlorine, chlorate or nitrate. Henderson (2004, personal communication) mentioned an important technology whereby an emulsion of oxygen microbubbles with leach solution is created using an ultra-sonic or sonic generator under pressure in order to achieve greatly elevated oxygen levels. This emulsified solution provides significant oxidizing capacity. Enough, it is believed, even to oxidize chalcopyrite.

Numerous large copper heap leaching operations have been successfully brought into production since the 1980's particularly in Chile, the USA, Mexico and Peru. Some of these operations treat oxide ores, whereas several treat chalcocite ores. These heap leaching successes are relevant to this white paper on in-situ leaching, because much of the same leach chemistry that has been successfully applied in heap leaching, can be applied directly also in in-situ leaching of copper. 
A sound knowledge of chemistry is essential to achieve successful ISL. Different leach solution chemistries are needed for different types of ores depending on their composition. For example, sulfuric acid is a commonly used lixiviant for oxide copper ores. However, all too often, real life observations depart from what one might expect after conducting a desk study.

Several patents (see Section 7) specific to in-situ leaching of copper focus on ways to improve the introduction and reactivity of oxygen with copper sulfides.

Van Poolen and Huff (1975) pointed out that the complexity and cost of two phase injection of water and oxygen may be reduced by using steam instead of water. Thus it was conceived that copper may be leached in-situ from several of its sulfides by injection of a gaseous mixture of oxygen and steam into the wellbore. Additionally, the oxidation produces sulfur trioxide and/or sulfur dioxide producing an acidic solution. The advantage of using steam and oxygen would be that it permits one-phase injection.

Injecting oxygen with the lixiviant can cause problems when gas bubbles coalesce and blind off the pores of the rock in the ore deposit. Surfactants can be added in small quantities to avoid coalescence of the bubbles and to enhance production of very small microbubbles $(<10$ $\mu \mathrm{m})$ that are able to pass through the formation.

Henderson (2004, personal communication) relates various efforts to demonstrate a method of sonically (or ultra-sonically) generating an emulsion of oxygen microbubbles in lixiviant solution that provided a greatly enhanced oxidizing capacity for in-situ leaching.

Huff and Associates, a firm based in the Denver area, patented a chlorine dioxidechloride lixiviant for gold that works well in the $\mathrm{pH} 6$ to 7 range. This solution is believed to offer advantages for leaching gold associated with oxide copper minerals.

Dr. Jaime Arias, in Chile, was developing the use of a combination of nitric acid and sulfuric acid to oxidize chalcopyrite ores. He presented a paper at one of the Randol Copper Hydromet conferences, and is currently believed to be promoting his chemical oxidation of sulfides under the name "Metex".

Beane (1999) described his perception of some of the solution chemistry challenges that need to be overcome to achieve successful in-situ copper leaching. His conclusions were drawn from personnel experience with in-situ leach solution chemistry at the San Manuel Oxide Operation. Based on a study carried out on leach solution compositions at numerous operations in the Western Hemisphere, it was apparent that many of the features described by Beane (1999) for San Manuel in-situ solutions extended more generally to heap leaching of copper as well.

Beane (1999) showed that typical sulfuric acid lixiviants used in in-situ leaching as well as heap leaching of copper, are magnesium, aluminum, and sulfate brines typically with sulfate at 1 mole/liter and the remaining three each at around 0.1 mole/liter. PLS has a titrated free acid concentration around 2 grams/liter corresponding to a $\mathrm{pH}$ of 1.4 . However, measured $\mathrm{pH}$ is 2.1 being higher on account of much hydrogen ions being tied up as $\mathrm{HSO}_{4}{ }^{-}$. He showed that acid consumption for the leaching of copper was only $25 \%$ of the total acid consumption at San Manuel Oxide ISL leach, the balance being consumed by reactions with gangue. He showed that dissolution of gangue minerals provides the large concentrations of aluminum and magnesium, in addition to iron, manganese and other cations in leach solutions. However, these components do not increase in mature leach solutions through continuous recycling. The only concentration changes observed during an injection-production cycle is an increase in copper and a decrease in hydrogen ions. Because of the decrease in hydrogen concentration from injection to production wells, leach solutions become saturated with, and deposit, new minerals along their flow paths. 
A study at San Manuel (Beane and Ramey, 1995) showed that although overall permeability in a leach field increased with increasing leach time, permeability adjacent to the production wells decreased. This results from acid raffinate dissolving material near injection wells and then redepositing it further along the flow path.

Precipitation of gypsum reduces permeability (Beane, 1999). Aluminum precipitation is a bigger factor in fracture filling than ferric iron precipitation. Precipitation of Fe results in reduced chalcocite leaching because ferric iron is needed as an oxidant. Both Fe and Al are kept in solution by maintaining low $\mathrm{pH}$. High $\mathrm{Al}$ concentrations also prevent copper sorption by clays.

Beane (1999) points out that a challenge remains to develop an economically viable lixiviant that reacts only with copper bearing minerals. That would yield optimal acid consumption and prevent aperture clogging by materials dissolved from gangue. In the absence of such a panacea, however, a reasonable goal would be a "soft leach" which maximizes copper dissolution while minimizing reactions with gangue. He suggests that this might be attained either by direct modification of leach solution composition, or by a pre-leach conditioning step to modify gangue mineralogy so that it reacts minimally with the lixiviant. Possibly the first step that would be achievable is lixiviant modification by optimization of acid content with regard to reactions with copper and gangue minerals.

In the USA, commercial uranium ISL projects today typically use alkaline chemistry employing sodium carbonate, and bicarbonate or ammonium carbonate solutions with sodium peroxide, hydrogen peroxide or oxygen addition as an oxidant. Alkaline carbonate leaching produces the soluble uranyl tricarbonate complex (actually a series of complexes).

Conversely, ISL uranium leaching projects in Eastern Europe, Russia and Australia use acidic chemistry employing sulfuric acid with oxygen, ferric ions and/or nitric acid added as oxidant (Mudd, 2001b). Sulfuric acid leaching produces soluble uranyl sulfate complexes.

In general, the uranium deposits in Wyoming were formed as a result of natural uraniferous solutions coming in contact with reducing agents, e.g. carbonaceous material or pyrite, that caused the uranium to precipitate out along with other metals such as vanadium. In Texas, uranium was precipitated out of underground water by reduction caused by methane gas. Consequently, the in-situ leachable uranium deposits in Texas tend to be "cleaner" than those in Wyoming according to Miller (2004, personal communication). Oxygenated leach solutions convert insoluble U (IV) into readily soluble U (VI) species that generally are present in solution as inorganic anionic complexes.

In recent times, particularly in the USA, injecting ammonia into groundwater has become less desirable, and sodium carbonate is preferred to ammonium carbonate. In Eastern Europe and Russia, sulfuric acid has been extensively used as a lixiviant for uranium, often with nitric acid as the oxidant.

Gold and silver can be leached using cyanide in alkaline solutions with oxygen or low levels of peroxide. The cyanide performs the role of complexing agent to keep the oxidized gold and silver ions in solution. Gold can also be leached using acidic chloride solutions or ammonium thiosulfate at near neutral $\mathrm{pH}$. Auric gold in chloride or thiosulfate complexes is less stable and generally more readily reduced back to gold metal than auric ions complexed by cyanide. Cyanide is generally a more selective lixiviant for gold than thiosulfate or chloride/chlorine.

Chloride/chlorine solutions at low $\mathrm{pH}$ can be considered, in principle at least, for the leaching of sulfidic base metal deposits and also gold. However, chlorine/chloride leach solutions are much less selective and reagent consumptions may be uneconomically high due to 
reactions with gangue minerals. Randol International Ltd, Golden, CO has developed proprietary concepts as to how chlorine/chloride lixiviants could potentially be more economically regenerated.

The innovation that is the focal point of this white paper relates to the physical aspects of bringing leach solution in contact with mineral values in the deposit. The benefits of this physical innovation would be applicable regardless of the lixiviant used since bringing solutions into more intimate contact with ore would benefit any leach chemistry system.

This white paper focuses on a means of improving the fragmentation of ore for in-situ leaching, describes a way to improve the distribution of lixiviant solution through the ore mass, provides a low cost and reliable means of oxygenating the process and provides a means of effectively collecting pregnant solutions and preventing fugitive losses. This technique will most likely find the most immediate applicability in the extraction of base metals from porphyry deposits. With that in mind, the most likely lixiviant will be sulfuric acid.

Sulfuric acid in-situ leaching has been used in the USA for copper at BHP's test site in Florence, AZ; at BHP's San Manuel in-situ leach project and at ASARCO's Silver Bell rubble leach project outside Tucson, AZ, all of which continued into the late 1990's. It has also been used for underground stope leaching of uranium at Denison Mines in Elliott Lake, Ontario.

Van Poolen and Huff (1975) proposed in-situ leaching of ore bodies containing copper even at moderate and great depths by injecting a gaseous mixture of oxygen and steam and producing a lixiviant optionally with the addition of sulfur trioxide or sulfur dioxide.

In the case of certain types of chemical leaching (e.g. gold by cyanide; uranium by sodium carbonate; and bioleaching of sulfide ores) introduction of oxygen into the ISL environment may be required. The novel method described herein provides a low cost, reliable means of doing this.

Over the last three decades or so, the technology of heap leaching (particularly for the extraction of copper, gold and silver, and more recently also from sulfidic copper ores) has advanced significantly. Heap leaching was originally developed for the treatment of oxidized copper, gold and uranium ores. More recently, heap leaching has been applied also in the treatment of sulfide ores, particularly chalcocite, with increasing success. This has been made possible by the advancement of bioleaching and bioheap leaching technologies.

The in-situ leaching concept that is the subject of this white paper creates a leaching environment similar to heap leaching, but offers better solution-ore contact and oxygenation than conventional run-of-mine heap leaching.

Acetic acid has been proposed by Geisler and Puddington (1996) as a lixiviant possibly used in conjunction with an oxidant to leach lead from lead sulfide minerals. The high concentrations of reagent required would however probably detract from the immediate economic viability of this technology.

Halogens, i.e. chloride/chlorine and bromide/bromine solutions and admixtures of halogens are less selective lixiviants, however, and reactions with gangue minerals are likely to result in high reagent consumptions for most ore types.

\section{c) Leach Solution Injection, PLS Recovery and Hydrology}

Single well leach tests are often carried out using a "push-pull" system in which leach solution is first injected (pushed) into the formation, and then the pregnant solution is pumped (pulled) out of the same well. 
In the late 1980's a Texas company by the name of Solution Engineering, Inc. developed and installed a commercial scale in-situ uranium leaching operation that recovered uranium from unconsolidated uranium mine tailings impoundments. von Michaelis (2004) recalls more than one paper presented on the subject by Joseph R. Stano.

In-situ leaching of uranium roll fronts in porous sandstone deposits has been the most widely practiced form of in-situ leaching. Considerable knowledge exists about the hydrology of such systems and about well field design and operation.

Typically, in-situ leach wells are arranged in a grid consisting of the well known "five spot" patterns with one injection well in the center of four production wells. When arranged in a grid this typically works out to 1.2 to 1.3 production wells per injection well. Well spacing depends on the porosity and permeability of the deposit (measured in millidarcies) but 30 to 40 $\mathrm{m}$ spacing is not uncommon. The general practice is to complete injection and production wells through the entire vertical dimension of the formation of interest, (Graves, 1985). Monitor wells, employed to monitor fluid flow and containment, are distributed around the periphery of the injection-production well field.

Well completions are similar to water wells, with casings perforated in the permeable, ore-bearing aquifers. The use of polyvinyl chloride casing, which is considerably cheaper than steel casing, limits depths of economic drilling to within $270 \mathrm{~m}$ of the surface. (Dennis Stover, VP Engineering and Project Development, Rio Algom Mining Corporation, as reported in National Academy of Sciences, 2002) The development of inexpensive casings that could withstand higher pressures would permit leaching of known deposits located at greater depths.

Leach solution travels in a radial pattern horizontally from the points of injection to the production wells. It must be remembered that uranium precipitation in a roll front results in a localized reduction in permeability of the formation right where it's needed the most. Depending on the degree of fracturing, the area within the mineralized zone of the formation that is actually contacted by leach solution can be quite small. Solutions tend to follow fissures and high permeability streaks. "Thief zones" of higher permeability surrounding the mineralized sections of the formations can cause substantial losses of injected fluids (Graves, 1985).

When pregnant leach solution (PLS) is pumped via production wells from an aquifer it can be relatively easy to engineer a cone of depression such that excursions of leach solutions to the rest of the aquifer are avoided or at least minimized.

The National Academy of Sciences (2002) pointed out that because development of ISL depends heavily on drilling and completion of the well field, improvements in drilling efficiencies (faster, cheaper drilling) would increase the productivity of in-situ mining. Directional drilling with sensors, for example, was indicated as one possible improvement.

Uranium in "dry formations" cannot be extracted by conventional ISL practices. However, minerals in "dry formations" may become leachable when the new ISL concept is employed, since it provides a means whereby a very high percentage of the ore zone can be contacted by leach solution.

The new concept for in-situ leaching presented in this white paper provides a practical means of generating a much more uniform fragmentation of the ore deposit and the overlying rock column with introduction of significant void space between the ore fragments. Solution will be introduced at the surface by spraying it on to the top of the column of fractured rock and ore. This ensures that a very much greater part of the ore gets wet by the leach solution. A limitation of the system is that the top of the orebody needs to be at or near the surface. The system can be conceptually applied also to mineralized pit bottoms. 
Leach solutions permeate the fractured ore body even more efficiently than in a heap leach operation, for reasons provided in the description, and pregnant leach solutions are then pumped from collection points located beneath the column of fractured ore as described. More ideally, the base of the leaching column of ore will be located within or above, but close to, the water table from which pregnant leach solution can be drawn creating a cone of depression as a means of preventing losses to the environment.

\section{d) Bioleaching of Metals}

The Committee on Evolutionary and Revolutionary Technologies for Mining (National Academy of the Sciences, 2002) reported: "The committee also rates as a high priority development of lixiviants and microbiological agents that can selectively dissolve the desired elements and leave the undesired elements in the rock."

Bioleaching of sulfide minerals involves the generation of acid and oxidant (ferric iron). Consequently, in-situ bioleaching can be viewed as a process by which both generation of the leaching agent and reaction of the leaching agent with the mineral of interest take place in-situ. Typically, bioleaching processes require the injection of air or oxygen, or are enhanced thereby.

The science and art of bioleaching has advanced significantly over the last twenty years with numerous commercial operations and several very promising demonstration plants testing new applications of bioleaching and biooxidation for the extraction of metals from sulfide ores. Specifically, biooxidation of sulfides technology has been applied to copper, refractory gold ores and is being extended to other metals such as nickel, cobalt, and zinc. Bioheap leaching has become well established on a large-scale commercial basis for copper. This technology appears readily transferable to the new concept for in-situ leaching described in this white paper.

The new in-situ leach system concept appears to provide an excellent environment for the application of bioleaching processes. Reaction temperatures can readily be controlled by the addition rate of aqueous solutions and by controlling the rate of oxidation through adjustment of the rate of air ingress. The column of ore will have adequate void space to allow the upflow of air through it in a well distributed and controlled manner. The configuration of the ore column will also provide a chimney effect when heat is released as result of biooxidation of sulfides. Nutrients in solution can be introduced in a controlled manner. Solution flow patterns will constantly be changing thereby eliminating blinding or dry spots within the ore column. Solution composition and application rates can be readily adjusted.

True "in-situ" bioleaching of uranium, analogous to chemical in-situ leaching described above, has not yet been developed. However, "in-place" bioleaching of uranium has been practiced in the Elliott Lake, Ontario region of Canada. Acidic mine water was sprayed onto mined-out stopes, and uranium leached by flooding the stopes. Additional in-place leaching was practiced on blasted, rubblized ore according to McCready and Gould (1990). Ontario experiences cold winters and a distinct improvement in uranium recovery was observed during the warmer months. von Michaelis (2004, personal communication) visited Elliott Lake in the 1980's and observed the in-place bioleaching of uranium in operation.

Elliott Lake uranium ores consist of Archean quartz pebble conglomerates with some pyrite contained in the matrix. Biologically induced oxidation of this pyrite generates sulfuric acid in place that in turn leaches uranium in the presence of an oxidant, namely ferric ions generated from biooxidation of pyrite. Similar processes are known to occur naturally on the Witwatersrand where some mine waters can contain moderately elevated uranium levels. These 
acid rock drainage generating processes could possibly be harnessed for uranium recovery in selected Witwatersrand mine stopes and waste dumps. This deserves further evaluation, notwithstanding the relatively lower grades of uranium in Witwatersrand ores, and constraints due to the need to protect aquifer water quality.

Acidophilic iron-oxidizing bacteria are able to leach uranium by oxidizing U(IV) to $\mathrm{U}(\mathrm{VI})$ in dilute sulfuric acid solution. The mechanism is generally considered to be indirect, i.e. the organisms maintain a high solution redox potential through oxidation of ferrous ions derived from iron sulfides in the ore. Ferric ions oxidize uraninite $\mathrm{UO}_{2}$ to $\mathrm{UO}_{2}{ }^{2+}$. The $\mathrm{UO}_{2}{ }^{2+}$ forms soluble $\left[\mathrm{UO}_{2}\left(\mathrm{SO}_{4}\right)_{\mathrm{n}}\right]^{2-2 \mathrm{n}}$ species.

Heap leaching of chalcocite copper ores involves a bio-oxidation step that generates sulfuric acid and liberates copper ions. The importance of injecting air (oxygen) under the oxidizing chalcocite ore heaps has been demonstrated over and again in commercial chalcocite heap leach operations. The innovation that forms the focus of this white paper provides a realistically possible way to enhance the leaching of chalcocite ores with sulfuric acid, by introducing appropriate bacterial inoculum, injecting air and through the creation of optimal temperature, $\mathrm{pH}$, nutrient, and moisture environments. Dissolution of copper should logically be greatly enhanced by the improved contact between leach solutions and in-situ ore fragments.

Hydrometallurgical research is progressing to extend the biooxidation of copper sulfide minerals to the effective treatment also of chalcopyrite, a copper mineral that oxidizes far less readily than chalcocite, for example. The bioleaching of chalcopyrite involves the application of thermophilic bacteria. The innovation that is the focus of this white paper will conceptually create an environment that is conducive to the application of thermophilic bacteria for bioleaching. Therefore a summary of the latest developments of bioleaching chemistry and technology is relevant here.

Bioheap leaching of copper from sulfide ores has also made significant advances. Brierley \& Brierley (2000) summarized the results for ten commercial operations treating chalcocite copper ores. Eight of theses are in Chile and two in Australia.

$\underline{\text { Table 6.1 Commercial Copper Bioleach Operations }}$

Plant Size (tonnes/day) Years in Operation

Lo Aguirre, Chile
Gunpowder Mammoth, Australia
Mt. Leyshon, Australia
Cerro Colorado, Chile
Girilambone, Australia
Ivan-Zar, Chile
Quebrada Blanca, Chile
Andaquollo, Chile
Dos Amigos, Chile
Zaldivar, Chile

Lo Aguirre, Chile

Gunpowder Mammoth, Australia

Mt. Leyshon, Australia

Cerro Colorado, Chile

Girilambone, Australia

Quebrada Blanca, Chile

Andaquollo, Chile

Zaldivar, Chile

$$
\begin{array}{r}
16,000 \\
\text { in-situ } \\
1,370 \\
16,000 \\
2,000 \\
1,500 \\
17,300 \\
10,000 \\
3,000 \\
\sim 20,000
\end{array}
$$

1980-1996

1991-present

1992-closure (1997)

1993-present

1993-2003?

1994-present

1994-present

1996-present

1996-present

1998-present

Bruynesteyn (2000) reported progress in developing technology for bio-leaching chalcopyrite. Olson et al. (2000) reported on test results showing that low-grade ores containing 
chalcopyrite bio-leached faster in column tests when subjected to thermophilic bacteria. Uhrie (2000) reviewed the chemistry of secondary sulfide copper ore leaching and some of the biooxidation mechanisms.

Brierley \& Brierley (2000) report costs of extracting and recovering copper by bioheap leaching between US $\$ 0.40$ to US $\$ 0.65$ per pound copper cathode. Given that a substantial part of these costs is for mining, leach pads, and heap stacking, it can be expected that in-situ leached copper will likely be producible using the innovative technology described in this white paper at a substantially lower cost.

Copper can be recovered from higher grade chalcopyrite ores by flotation, but lower grade ores cannot be economically leached because chalcopyrite tends to passivate after only partial extraction of copper. The extent of passivation varies with the ore and with the leaching conditions. Early studies attributed the passivation to a layer of elemental sulfur formed as oxidation proceeded. However, more recent work suggests passivation results from a refractory, iron deficient copper sulfide layer that forms on the surface or the mineral. Only extreme fine grinding or use of thermophilic biooxidation seems to prevent passivation. Recently it has been suggested that high solution redox potentials cause passivation of chalcopyrite and that maintenance of a slurry "redox window" of $350 \mathrm{mV}$ to $450 \mathrm{mV}$ (versus standard calomel electrode, or 595 to $695 \mathrm{mV}$ versus standard hydrogen electrode) permits improved biooxidation (Pinches et al., 2001). However, this concept has not been shown to apply to a wide variety of chalcopyrite ores. We found biooxidation of a chalcopyrite ore proceeded readily at relatively high redox potentials $(800 \mathrm{mV}, \mathrm{SHE})$ in the presence of extremely thermophilic microorganisms at $65^{\circ} \mathrm{C}$ (unpublished results). Additionally, ore that passivated at $35^{\circ} \mathrm{C}$ resumed bioleaching when heated to $65^{\circ} \mathrm{C}$.

The main roadblock to applying thermophilic microorganisms for biooxidation of chalcopyrite in heaps is establishing and maintaining temperatures conducive to their growth. Sufficient "fuel" (i.e., pyrite) must be present in the ore to be oxidized and heat the heap, and a means of temperature control is required. In this regard, ISL offers exciting possibilities. First, the insulating conditions present during biooxidation of chalcopyrite in-situ would permit the development of warm temperatures even at relatively low rates of sulfide biooxidation. Deeper ore deposits may already be at temperatures permitting thermophilic biooxidation. Reaction rates could be controlled by the rate of introduction of air which is facilitated by the new concept described herein. This "chimney effect", whereby air enters through the constructed decline, drawn in by the upward flow of heat convection, offers an interesting prospect for controlled temperature thermophilic bioleaching.

\section{$\underline{\text { General Issues Relevant to Using Microorganisms In-Situ }}$}

Use of microorganisms for in-situ leaching of metal ores has not been developed, though for many years there has been great interest in the potential for this technology. A number of exciting possibilities exist for combining the new ISL concept described in this white paper with biooxidation of minerals in the subsurface.

Bioleaching likely would be initiated by introducing organisms, pregrown on the surface and injected into the deposit. However, deep ore bodies are not necessarily devoid of microbial life. The occurrence of thermophilic, anaerobic microorganisms in deep subsurface environments has been known for a long time (ZoBell, 1958; Olson et al., 1981). As in bioheap leaching, introduced organisms may initiate a process but with time selection will occur for 
organisms, introduced or naturally occurring, best suited for growth under conditions present in the ore body.

Encouragement of microbial growth in-situ is not without potential problems. In particular, solution flow may be adversely affected by microbial growth or oxidation products. For example, growth of microorganisms during in-situ chemical leaching of uranium is believed to be one of the causes of flow path plugging in the ore body. A laboratory study showed inoculation of mixed cultures of bacteria into a uranium core specimen reduced permeability. The reduction was overcome by hydrogen peroxide which killed the organisms (Yates et al., 1983). Injection of bacteria into rock with very small pores results in little penetration; the cells are filtered out close to the injection well (McInerney and Westlake, 1990). In the case of acidophilic iron- and sulfur oxidizing microbial processes, precipitation of jarosites from biogenic acid mine drainage solutions can impede solubilization of uranium minerals and should be minimized (McCready et al., 1986). However, the proposed new process should create sufficiently fractured ore permitting good solution flow. Indeed, it may be closer in situation to the microbiologically-assisted in-place leaching of uranium and copper (Sand et al., 1993) in rubblized stopes that has been practiced. Movement of ore within the ore column also is envisioned in the new process and is likely also to cause some surface attrition of the ore particles which should be beneficial with respect to reduction of the plugging effects described above.

Thermophilic microorganisms especially may have significant applications with in-situ leaching, particularly in deeper deposits. Again, solution chemistry must be evaluated with respect to the potential for precipitation of minerals and its resultant effect on solution flow (Jacobson et al., 1989). For example, jarosite precipitation is much more significant at elevated temperatures $\left(75^{\circ} \mathrm{C}\right.$ to $80^{\circ} \mathrm{C}$ ), particularly at $\mathrm{pH}$ values above 1.3 (Norton et al., 1991). Calcium sulfate (gypsum) is less soluble at elevated temperatures and its precipitation in-situ could severely restrict solution flow, as has been observed in thermophilic bioleaching columns (Olson et al., 1998). Again, the new concept described in this white paper provides movement and attrition within the ore column that could mitigate these effects.

Sulfide mineral biooxidation in-situ will require introduction of oxygen. In the new process envisioned in this white paper, a significant flow of air is expected from the chimney effect of a heating ore body. The flow rate of this air can be controlled which in turn will control biooxidation rate, heat production, and leaching rate.

Anaerobic processes might also be considered where bioreduction might be advantageous. For example, a number of oxidized metal species can be bioreduced using hydrogen or simple organic compounds as reductants. These reductions include U(VI) to U(IV), $\mathrm{Fe}(\mathrm{III})$ to $\mathrm{Fe}(\mathrm{II}), \mathrm{V}(\mathrm{V})$ to $\mathrm{V}(\mathrm{III}), \mathrm{Cr}(\mathrm{VI})$ to $\mathrm{Cr}(\mathrm{III})$, among others (Lovley, 2000). These reductions generally lead to metal precipitation, not mobilization. However, the reduction of $\mathrm{Fe}(\mathrm{III})$ to soluble $\mathrm{Fe}$ (II) might be considered in cases where ferric precipitates (iron hydroxides or jarosites) coat reactive minerals or block solution flow.

Finally, microbial in-situ formation of organic acids or chelators able to mobilize certain minerals also might be considered. Many neutral $\mathrm{pH}$ microorganisms produce such leaching agents from the oxidation of organic substrates. Again it must be kept in mind that excessive amounts of introduced organic materials can lead to significant biomass formation and plugging.

In-situ biooxidation of refractory sulfidic gold ores may be a pretreatment step to increase subsequent leaching of gold, as is practiced commercially in stirred tank and bioheap processes (Olson et al., 2003). Gold locked in pyrite or arsenopyrite is made available for subsequent 
extraction by biooxidation of the sulfides. The basic requirements for this process would be similar to those required for bioleaching of copper ore.

As discussed above, lixiviants for gold other than cyanide are sought. Among biogenic agents, hydrosulfide anion is a lixiviant for gold. Hydrogen sulfide production from microbiological sulfate reduction underground is a common and widespread process. Although hydrogen sulfide is no less toxic than cyanide, there may be situations in which it could be safely used to extract gold. Furthermore, in the presence of air it is readily oxidized biologically or chemically.

Microorganisms are able to produce cyanide from certain substrates and leach gold (Campbell et al., 2001). Such a process potentially could be performed in-situ. However, there could be problems related to biomass plugging of the deposit. Additionally, a strategy would have to be developed to ensure indigenous microorganisms might not outcompete cyanideproducing bacteria for the substrate. Furthermore, the potential problems related to cyanide use in-situ would remain. In any case, cyanide is also readily biodegradable. The in-situ leaching system described in this white paper lends itself to biodegradation of cyanide in-situ on completion of gold leaching by simply changing the solution chemistry and by inoculation with appropriate bacteria during the reclamation stage.

Cyanide is the best lixiviant for gold and silver that has been developed to date. It is selective, applied in very low concentrations and degradable on completion of the leaching task. Objections to cyanide as a gold lixiviant are mostly emotional and based largely on perceptual psychological grounds not supported by scientific fact. The new in-situ leaching technique described here may prove ideally suitable for use of cyanide in conjunction with biodegradation.

Of course, many of the considerations discussed above for chalcopyrite and refractory gold ores apply to bioleaching of other minerals. Sulfide mineral biooxidation rates increase with temperature. Consequently, leaching will be increased in warm underground ore deposits.

The in-situ leach technology that is the focus of this white paper lends itself to the application of the same leaching technology used for heap leaching and bioheap leaching, but applied to deposits that cannot be economically mined by conventional techniques. In addition the new in-situ leach technology promises to create a means of optimizing the leach process in a manner that is not possible in conventional heap leaching or bioheap leaching.

\section{e) Metal Recovery from Leach Solutions}

Once valuable metals have been leached in-situ, the pregnant leach solution will be collected and pumped to the surface for metal recovery. Various recovery techniques have been used in the past. These include:

- Cementation. Examples include cementation of copper using iron cans, or cementation of gold from solution using zinc dust or zinc shavings. Cementation of copper on iron was used in Cuba to recover copper from PLS generated at the Naciomientos copper ISL test project. Cementation was also used in a primitive way in the first informal experiments in ISL in ancient times.

- Solvent extraction and electrowinning (SX-EW). SX-EW is widely used for the recovery of copper from acid heap leach solutions. Cupric ions are extracted by organic amines from leach solutions. Generally, for SX-EW to be cost-effective, the tenor of the leach 
solution needs to be quite high. Ness (2000) provides basic principles, processes, chemistry and hardware for copper SX-EW and Spence (2000) presented insights into extractant considerations in copper SX-EW.

- SX not only concentrates the ions ahead of electrowinning but reduces the concentration of ions that are deleterious to EW.

- Solvent extraction and precipitation. SX has been successfully used for uranium recovery from leach solutions in uranium milling circuits treating higher-grade uranium ores following leaching, solid liquid separation and clarification steps. After being extracted by an organic solvent (typically kerosene) containing organic ingredients (such as tertiary amines), the loaded organic solvent is then recovered in mixer-settlers and then stripped to yield a concentrated aqueous pregnant solution from which uranium is chemically precipitated using ammonium or peroxide solution additions.

- Solid Ion Exchange. Dilute pregnant leach solutions such as those likely to be generated by in-situ leaching are generally more amenable to metal recovery using solid anion ion exchange. Various ion exchange resins are available. Fixed bed ion exchange systems require prior clarification of the pregnant solution. A benefit of upflow fluid-bed ion exchange metal recovery systems is that the relatively expensive and operator intensive pregnant leach solution clarification step can be eliminated. Loaded ion exchange resins are then transported to an elution cell where the metal is eluted (stripped) from the resin beads to form a concentrated solution from which metals (e.g. copper and nickel) can then be electrowon, or in the case of uranium can be precipitated to make yellowcake.

- Recently the successful new "Pumpcell" technology developed for carbon-in-pulp recovery of gold has found growing application in South Africa and elsewhere. Pump cells (applied in a resin-in-solution mode) appear eminently suitable for the recovery of uranium, gold and/or copper by adsorption from pregnant leach solution onto solid ion exchange resin beads.

- Uranium is stripped from loaded anion exchange resin, and the uraniferous eluate is separated from the base anion exchange resin, and thereafter is generally recovered by treating the uraniferous eluate by first acidifying it and then treating it with ammonia to produce a relatively pure ammonium diuranate.

- South Africa's MINTEK has developed and demonstrated ion exchange resin processes for the recovery of gold from cyanide leach solutions.

- Direct Electrowinning. New direct electrowinning technology and hardware systems have been developed that make it possible to selectively electrowin metals such as copper, nickel and cobalt from acidic solutions. One such system is the Electrometals Technology Ltd. EMEW cell which claims to be able to achieve improved current efficiencies at lower metal concentrations in the electrolyte. In general, the current efficiency for metal recovery by direct electrowinning improves as the concentration of the metal to be recovered increases. Around 1999, on a trip to Queensland, von 
Michaelis (2004, personal communication) recalls being told by Electrometals Technologies Ltd. that EMEW cells were being used to recover copper at a small semicommercial scale in-situ leach operation in Queensland. Lately the application of EMEW cells to the direct electrowinning of silver from cyanide solutions is attracting industry attention.

- Reverse Osmosis has evolved to a stage where it can be applied to recover water while concentrating reagents and metal ions in the concentrate. Reverse osmosis can now be considered in lieu of SX ahead of electrowinning or precipitation for metal recovery.

- Ultrafiltration and cross-flow filtration can be considered as a potential means of dewatering yellowcake precipitated from pregnant aqueous eluates after stripping loaded SX solutions and or after eluting loaded resins.

- Electrowinning of base metals from chloride solutions offers distinct fundamental advantages over electrowinning from sulfate solutions.

\section{f) Environmental Management and Reclamation}

The Committeee on Evolutionary and Revolutionary Technologies for Mining of the National Academy of the Sciences (2002) wrote: "Key environmental and health concerns raised by in-situ leaching are the possibility of potentially toxic elements being brought into groundwater. For example, selenium, arsenic, molybdenum, and radioactive daughter products of uranium are concerns in mining sandstone-type uranium deposits. Therefore, the committee also rates as a high priority development of lixiviants that can selectively dissolve the desired elements and leave the undesired elements in the rock."

Post-mining water quality is the major environmental concern of in-situ leaching. Again, quoting from the National Academy of the Sciences committee report: "The closure of in-situ leaching facilities raises an additional environmental concern, especially in the copper industry where large-scale in-situ leaching of oxide ore bodies above sulfide workings and leaching of sulfide (particularly chalcocite) ores have been conducted. During operations the maintenance of a cone of depression around these ore bodies and the continuous extraction of product solution limits the release of lixiviants and mobilized metals to the surrounding aquifer. However, once mine dewatering and solution recovery are completed, there may be a significant potential for the transport of metals and residual leaching solution. To the extent that the ore body is again totally immersed in the water zone, metals will be in a reduced state, and their mobility will be limited" (...last sentence questionable?)...However, if leaching has taken place above the water table, metals may continue to leach if meteoric water penetration and bacterial activity are sufficient to produce acid conditions. Research should, therefore, also include the evaluation of how these facilities can be closed without long-term adverse impacts to groundwater quality."

von Michaelis (2004 personal communication) came away after visiting an in-situ copper leaching site in Arizona, with the feeling that questions about post-operation prevention of acid generation and mobilized metals release remain to be satisfactorily answered.

Conceptual features of the new in-situ leach concept provide a means of much better (than existing copper in-situ leach operations) post-leaching control of solution and air ingress 
into the leached out ore body. This is the key to preventing, or at least greatly reducing, release of lixiviants and mobilized metals to ground water environments. It remains to advance this from a conceptual to practical demonstration stage, as the practical aspects of implementation still need to be fully developed.

Subsurface environmental aspects of in-situ leaching are today recognized as being of critical importance. Preserving groundwater quality is vitally important and is an increasingly critical issue all over the world. This aspect of in-situ leaching is of such critical importance that it must receive significant attention in the further development of the new concept for in-situ leaching described in this white paper.

Surface facilities for in-situ leaching operations are unobtrusive and ISL operations appear to be environmentally friendly. There is no big open pit, no waste piles, no tailings impoundment, no headframe, no mill and concentrator no large workshops, no truck fleet.....just some nice orderly pipes and pumps and a small clean looking facility for metal recovery. In-situ leaching operations appear in all respects to be a "good neighbor". They can be so if designed properly and if appropriate environmental precautions are taken in advance.

Uranium in-situ leaching extracts metal from porous sandstone rollfront deposits located within aquifers. In most cases in the USA the mineralized deposits that are in-situ leached are in aquifers that are sandwiched between impermeable rock, shale or clay layers, such that contamination of lixiviant or leachate metal ions is isolated from overlying and underlying aquifers.

As described above in section (b), extensive uranium in-situ leaching has been practiced in Eastern Europe and Russia where no advance consideration was given to protecting water quality in the aquifers. This has resulted in extensive environmental damage as described by Mudd (2001b). Repairing the damage retroactively will be very expensive, and may not be affordable to an extent that prevents future beneficial use of the impacted aquifers.

The fact that environmental damage to aquifers as a result of ISL of uranium in the eastern Europe and Russia, where acid leach systems are employed should not be the cause for a prejudicial stigma against acid ISL systems.

From the beginning there was a marked difference in concern for and attention to the environment between ISL uranium leaching projects in the USA and Australia, on one hand, and those in eastern Europe and Russia (Mudd, 2001a,b). In US uranium ISL projects significant care has been taken to avoid damage to aquifers. Test ISL projects have been required to demonstrate that the project design and reclamation techniques can avoid contamination prior to going into commercial operation, and all projects are required to be carefully monitored.

In the case of uranium, concentrations of uranium, and its associated radioactive daughter products and, in some cases potentially toxic elements, such as arsenic, vanadium and selenium could become elevated (National Academy of Sciences, 2002). Site reclamation has been successful at several south Texas sites where ISL of uranium was first undertaken in the 1970s. In-situ uranium leaching has advantages in terms of health and safety because the leaching process selectively removes uranium and leaves most of the dangerous radioactive daughter products in the ground. Also, little heavy machinery is employed to remove the large volumes of rock that would have been processed in a conventional mining operation. Dust generation, a growing concern at open pit operations, is also not an issue in ISL operations.

Mudd $(2001 \mathrm{a}, \mathrm{b})$ has undertaken a careful study of acid ISL of uranium around the world. His papers provide excellent insights into the critical importance of designing ISL projects in such a manner that contamination of groundwater aquifers is avoided. They also provide 
excellent insights into the damage to groundwater that has resulted in Eastern Europe and Russia when such precautions were not taken. Mudd $(2001 \mathrm{a}, \mathrm{b})$ clearly shows that repairing damage to groundwater after the fact is generally much more costly than avoiding the problem in the first place.

Hunkin et al. (1979) outlined a method of reclaiming uranium deposits after the uranium in the ore has been removed by ISL. Once uranium has been recovered to the extent that is economically possible, the aqueous ammonium carbonate plus peroxide oxidizing leach solution is replaced by an aqueous reducing solution that is passed through the ore deposit to precipitate and render insoluble any residual uranium and metals such as vanadium, molybdenum and selenium. This process produces a very low volume of above ground impurities and waste solutions requiring disposal, and causes no significant contamination of the underground deposits or any aquifer associated therewith. 


\section{IN-SITU LEACHING PATENTS}

Although there are numerous patents describing means of improving in-situ leaching through better ore fragmentation by blasting, none was found that offers the benefits and features of the innovation that is the focus of this white paper. Examples of relevant patents are summarized below.

\section{Ore Preparation \& Physical Systems:}

US Patent 2,954,218 September 27, 1960

John N. Dew and William L. Martin Assigned to Continental Oil Company In-situ roasting and leaching of uranium ores

A method of recovering soluble minerals, such as uranium, vanadium, and radium from subsurface ores. The invention involves the injection of oil which is burned in-situ to oxidize naturally occurring carbonaceous species in the ore, rendering the valuable metals soluble in lixiviants with oxidation by oxygen injection.

US Patent 3,309,141 March 14, 1967

John L. Fitch and Billy George Hurd Assigned to Mobil Oil Corporation Method of leaching subsurface minerals in-situ

A method for sealing off the formation surrounding an in-situ leach ore deposit by injecting an inert fluid into the formation surrounding a pod of ore contemporaneously with injecting a leaching solution into the pod of ore. The rates of injecting the inert fluid into the formation, the leaching solvent, and the inert fluid following the leaching solvent into the pod of ore are adjusted to establish a pressure gradient between the inert fluid in the surrounding formation and the leaching solvent in the pod of ore where pressure gradient is adequate to prevent the flow of the leaching solvent out of the pod of ore into the surrounding formation.

US Patent 4,045,084 August 30, 1977

Limin Hsueh, Robert A Hard, Donald H. Davidson, and Ray V. Huff Assigned to Kennecott Copper Corporation

In-Situ Mining of Copper and Nickel

A process for in-situ mining of copper from a subterranean ore body characterized, at least in part, by the presence of sulfidic ores and by natural, microscopic fracture openings. The process comprises forcing a stable, two-phase lixiviant comprising an aqueous phase, a multiplicity of gaseous, oxygen containing bubbles having a size sufficient to pass through the natural fracture openings in the ore body, and a surfactant for enhancing the formation of bubbles and for minimizing bubble coalescence through the ore body to leach copper.

The aqueous and gaseous phases are mixed at the surface and injected into the leaching interval through an injection hole, or preferably, are mixed in a subterranean sparger within the hole above the leaching interval. The pregnant liquor is recovered through one or more production holes and, after the copper is recovered, the lixiviant may be reconstituted and recirculated. 
US Patent 4,381,873 May 3, 1983

Clyde V. Johnson and Wilhelmus G.J. Huijnen

Assigned to Occidental Research Corp.

In-situ roasting and leaching of sulfide minerals

A process for recovery of metal values from an ore body containing sulfide minerals. The ore body is fractured for increasing its permeability. The fractured ore body is then roasted in-situ to increase the permeability and porosity of the ore body to liquid leach solutions. The roasted sulfide minerals in the ore body are thereafter contacted with a leach solution to extract metal values therefrom and the extracted metal values are recovered.

US Patent 3,841,745 October 15, 1974

Lucien Girard and Robert A. Hard

Assigned to Kennecott Copper Corporation

Stimulation of production well for in-situ metal mining

Metal values are economically leached in-situ by rubblizing a portion of an ore body, injecting a lixiviant for the metal values through one or more injection wells in the ore body located adjacent to but outside the rubblized chimney portion of the ore body, and collecting the lixiviant containing the dissolved metal values from one or more production wells located in a rubblized zone of the ore body. Reference is made to the application of underground nuclear detonations to fracture ore in underground deposits.

\section{US Patent 3,822,916 July 9, 1974}

\section{Charles H. Jacoby}

Patent assigned to Akzona Incorporated

In-situ extraction of mineral values from ore deposits

A hydraulic fracturing technique is described that allows explosives to be injected into an otherwise low permeability "hard rock" underground ore zone. Detonation of the explosive fractures the overlying rock rendering it more permeable to leach solutions. If sulfide type ores are involved, oxygen or air and water may be employed as an in-situ solvent/reactant.

US Patent 3,823,981 July 16, 1974

Arthur E. Lewis

Assigned to the US Atomic Energy Commission

In-situ leaching solvent extraction-process

A nuclear explosive is detonated in an ore deposit below the water table to provide fragmented ore in a nuclear chimney that serves as an in-situ pressure vessel. The vessel is filled with water from external sources or by flow from the formation and oxidizing gas is bubbled through the ore to oxidize and dissolve metal values therein. An organic extractant solution is then contacted with the aqueous phase in solution and is circulated to the surface where the metal values are recovered therefrom. Following makeup the organic phase is recycled into the nuclear chimney.

US Patent 3,999,803 December 28, 1976

David Linn Coursen

In-situ leaching of explosively fractured ore bodies 
Producing a fracture network in an ore body by detonating explosive charges sequentially in separate cavities therein, the detonations producing a cluster of overlapping fracture zones and each detonation occurring after liquid has entered the fracture zones produced by previous adjacent detonations. High permeability is maintained in an explosively fractured segment of rock by sweeping liquid through the fracture zones with high-pressure gas, between sequential detonations therein so as to entrain and remove fines therefrom. Ore bodies prepared by the blast/flush process with the blasting carried out in substantially vertical, optionally chambered, drilled shot holes can be leached in-situ via a number of holes previously used as injection holes in the flushing procedure and a number of holes which are preserved upper portions of the shot holes used in the detonation process. In the leaching of ore, fines are removed from fractures therein by intermittent or continuous flushing of the ore with lixiviant and high-pressure gas, e.g. air, using, in the case of the in-situ leaching of an explosively fractured ore body, a lateral and upward flow of lixiviant from zones that have been less severely, to others that have been most severely worked by multiple detonatons in the ore body.

When blasting in the absence of a free face for the ore to swell toward, it becomes necessary to employ special blasting and associated techniques which will provide and maintain the type of fracture network required for efficient leaching.

US Patent 4,586,752 May 6, 1986

William E. Showalter

Assigned to Union Oil Company

Solution Mining Process

A solution mining process for recovering mineral values from a subterranean mineralbearing formation, that includes: (1) an initial injection-and-production phase during which a leaching solution is injected into the formation and a pregnant liquor is simultaneously recovered from the formation, (2) a production-only phase during which injection is suspended and additional pregnant liquor is recovered from the formation, and (3) a second injection-andproduction phase.

US Patent 6,193,881 Feb 27, 2001

Kenneth J. Hsu

Assigned to Tarim Associates for Scientific Mineral and Oil Exploration AG In-situ chemical reactor for recovery of metals or purification of salts.

An in-situ reactor with hydrologic cells is provided to facilitate recovery of metals such as gold from rocks, or purification of salts such as potassium or magnesium chloride formed by evaporation of brines, by injecting into a source aquifer a fluid, which flows through and reacts with the solids or host rock within the in-situ reactor and then flows into a sink aquifer, from which it is drained or pumped out via an exhaust borehole into a plant or facility for further chemical treatment.

US Patent 4.311,340 January 19, 1982

William C. Lyons, Cheryl K Rofer-De-Poorter, Donald B. Buddecke, and Edward A. Zublin.

Uranium leaching process and in-situ mining 
A process for reduction or elimination of underground pollution by determining the geology of the ore and thereafter isolating the body by the formation of an impermeable barrier thereabout which has the capability of retaining leaching fluid therewithin. Leaching fluid remains downhole without substantial dilution by formation fluid, and conversely without pollution of the surrounding formation, until the mineral values are chemically changed into a recoverable substance which is subsequently pumped to the surface. Also proposes pumping an organic extractant down the hole to extract the uranium values.

US Patent 4,630,868 December 23, 1986

Arfon H. Jones and Sidney J. Green

Assigned to Terra Tek, Inc.

Process for solution mining

Invention uses fluids to fracture the formation in which the ore is hosted to increase the permeability of the formation through the use of proppants to enhance in-situ leach recovery of valuable metals.

\section{US Patent 5,645,322 July 8, 1997}

Kenneth Hsu, Peter Hsu and Frank W. Dickson

Assigned to Tarim Associates for Scientific Mineral and Oil Exploration

In-Situ chemical reactor for recovery of metals and salts

An "in-situ reactor" to facilitate recovery of metals and salts such as potassium, lithium, gold from salt-bearing natural waters, sediments, and rocks by passing a fluid containing such metals and salts through a reactive chemical bed placed at the bottom of a reactor, the metal and salt-bearing fluid flowing through the reactive chemical bed to react with the active components to produce a fluid from which the metals and salts can more easily be extracted.

\section{Chemistry of In-situ Leaching:}

US Patent 3,708,206 Jan 2, 1973

Robert A. Hard and Robert L. Ripley

Assigned to Union Carbide Corporation

Process for leaching base elements, such as uranium ore, in-situ.

A process for leaching base metals such as uranium, from an underground water saturated ore deposit containing oxidizable materials such as sulfides, carbon and the like. An oxygen bearing gas is introduced into the ore under pressure prior to (or simultaneously with) injection of a leach solution to oxidize the base metals within the ore deposit to a soluble state where they can then be dissolved into the leach solution. Thereafter the pregnant solution is withdrawn and treated by conventional techniques to remove the base elements.

\section{US Patent 3,860,289 January 14, 1975}

\section{Robert P. Learmont}

Patent assigned to United States Steel Corporation

Process for leaching mineral values from underground formations in-situ

A process for leaching mineral values from an underground formation in-situ, applicable particularly to uranium. In accordance with known practice, an aqueous solution of leaching 
agent (alkaline or acid) is delivered into the formation, where it remains for a prolonged period, and then is pumped out with dissolved mineral values. Some minerals occur naturally in a relatively insoluble form, and can be leached only if first oxidized to a more soluble form. An example is uranium oxide, which occurs naturally in the plus-four valence state $\left(\mathrm{UO}_{2}\right)$ and must be oxidized to the plus six valence state $\left(\mathrm{UO}_{3}\right)$ to enable it to be leached. Invention is to introduce oxygen to the leaching solution at a substantial depth within the injection well where the head of solution above increases the solubility of oxygen in the solution.

US Patent 3,881,774 May 6, 1975

Hendrik Karel van Poolen and Ray Vincent Huff

Assigned to Kenecott Copper Corporation

Oxidation of sulfide deposits containing copper values

Recovery of copper values by in-situ mining achieved by injecting a gaseous mixture of oxygen and steam and producing a lixiviant optionally with addition of sulfur trioxide or sulfur dioxide. Recovery of copper values at moderate and great depth can be achieved.

US Patent 4,155,982 May 22, 1979

Geoffrey G. Hunkin, Thomas P. Fife and Joseph R. Stano

Assigned to: Wyoming Minerals Corporation

In-situ carbonate leaching and recovery of uranium from ore deposits

Describes lixiviant for uranium consisting of 0.5 to 5 grams per liter ammonium bicarbonate, and from 0.1 to 3 grams per liter peroxide, preferably introduced as aqueous hydrogen peroxide, and sufficient ammonia to bring the solution $\mathrm{pH}$ to 7.4 to 9.0 and preferably from 7.5 to 8.5 . This lixiviant is relatively selective for uranium. Following leaching, a reducing solution is passed through the deposit to precipitate and fix vanadium, molybdenum and selenium.

US patent 4,185,872 Jan 29, 1980

Edward T. Habib

Assigned to Mobil Ol Corporation

In-situ leaching of uranium

Application of an aqueous lixiviant having a $\mathrm{pH}$ of at least 6.0 and containing an alkali metal sulfate leaching agent. The alkali metal sulfate may be employed in combination with an alkali metal carbonate or bicarbonate with the sulfate comprising the predominant leaching agent. The lixiviant may be at a $\mathrm{pH}$ of at least 7.5 and contain an alkali metal sulfate agent and a hypochlorite oxidizing agent.

US Patent 5,358,699 October 25, 1994

Thomas J. Clough

Assigned to Ensci, Inc.

Precious metal recovery process from carbonaceous ores

A process for leaching precious metals from an ore containing carbonaceous materials that render the ore refractory to cyanide leaching. The process employs certain plant derived ortho-quinone containing components, in particular certain lignin and/or tannin derived components containing ortho-quinone functionality. 
Preferred compositions comprise at least one lignosulfonate component containing orthoquinone functionality. In the process the use of at least one additional oxidant, capable of maintaining the ortho-quinone containing functionality in the desired oxidation state provides for integrated process synergy.

US Patent 5,523,066 June 4, 1996

Robert A. Geisler and Ira E. Puddington

Assigned to Centaur Mining Exploration Limited

Treatment of Lead Sulphide Bearing Minerals

A process for solubilizing lead contained in sulfide ores by in-situ leaching with acetic acid and acetate containing solution in the presence of an oxidant. The in-situ leaching is conducted by means of drillholes in the ore body. In another embodiment, the acetic acid and acetate containing solution is percolated through a bed of crushed untreated rock or unconsolidated mineral particles, mill tailings and/or agglomerated or unagglomerated sulphidic lead containing waste materials forming a pile or layer in an open vat, in the presence of an oxidant. Lead is recovered from the pregnant lead acetate containing solution and the solution may subsequently be recycled to further leaching of lead sulfidic minerals or lead sulfide containing particles.

US Patent 5,626,648 May 6, 1997

William P.C. Duyvensteyn and Matt Omofoma Assigned to BHP Minerals International Inc. Recovery of Nickel from Bioleach Solution

A bioleaching method is provided for recovering nickel from nickel laterite ores, nickel sulfide ores and/or concentrates produced therefrom. Lateritic nickel can be leached by an aqueous solution containing at least one microorganism selective for the leaching of lateritic nickel at a $\mathrm{pH}$ of around 1 to 2 . Sulfide nickel ores can be leached using acidified solutions containing bio-oxidizing bacteria also between $\mathrm{pH} 1$ and $\mathrm{pH} 3$, including a nutrient for the bacterial growth.

\section{US Statutory Invention Registration H2005 H}

Richard Winby, Paul C. Miller, Anthony Pinches, Lenhart G. Maritz Process for leaching low sulphur content materials

A process for leaching low sulfur materials for recovery of metals contained in them. Leaching of a low sulfur containing ore containing metal values with a leaching agent produced by bacterial agent produced by bacterial oxidation of a second material by bacterial action thereby liberating metal values from the first material substantially by an indirect bioleaching process. 


\section{DETAILED DESCRIPTION OF THE NEW CONCEPT}

\section{Summary}

The winning of metals from the earth has historically involved mining the ores using either underground or open-pit mining methods followed by processing of the ores to concentrate or extract the metals in some type of above ground treatment facility. In-situ extraction of some highly soluble or easily liquifiable minerals (such as phosphates, salt and sulfur) has been commercialized. The recent advent of heap leaching technology and large scale earth moving equipment has resulted in making large tonnage low grade deposits economically viable due to economics of scale and/or production of refined metals on-site (thereby circumventing cost prohibitive concentrate shipping, handling and treatment charges). The emphasis over the last 20 years has leaned towards developing increasingly larger deposits due to improved economics of scale. Small, low-grade deposits may not be large enough to realize sufficient benefit from economics of scale to render them viable.

In-situ leaching of metals has been investigated and undergone experimentation in the past few decades and has been tried in a number of different formats for a variety of metals. These efforts have been generally directed towards extraction of the metals from the rocks using some type of chemical solvent or collector coupled with collection and pumping of the pregnant solvent from within the deposit to an on-site treatment plant for refining. In almost all of the literature, the solutions are injected into the ore deposit through drilled wells and subsequently extracted using these same wells or other wells drilled for the expressed purpose of extracting the pregnant solution. Various patents deal with ways in which the "porosity" or "percolation rate" of the deposit are increased by fracturing the deposit using various types of explosives (including thermonuclear devices), hydro-fraccing or actual dissolution of some or all or the host rock to increase the solution flow rate and/or wetted surface area and thereby the extraction rate and/or ultimate recovery of in-situ metals or minerals. Other patents deal with methods of aerating the rock mass by injecting compressed air, oxygen or oxygenating chemicals into the deposit. Oxygen is needed for metal dissolution and acid formation.

The mining and extraction process proposed herein contemplates establishing a system of underground drawpoints beneath a leachable deposit from which a slot raise (or raises) is driven to surface to act as a primary opening for blasting the entire deposit as a single event and undertaking in-situ leaching of the entire deposit over a very long time period. It is envisaged that the leaching process would continue for many years until either all leachable material has been extracted or the daily recovered metal revenue decreases to a point where it is less than operating costs.

The sequences of events for this new concept are as follows. The surface expression of the deposit is stripped of topsoil which is stockpiled for future replacement as a capping on the deposit when extraction is complete. The entire ore body is then drilled off from surface for blasting. In practice, multiple slots will be established and the deposit may be blasted in multiple events over a short time period of a few weeks to months. Concurrently, a decline is driven to establish the draw points and undercut system through which the leach solution is collected and mucking of broken ore is undertaken to keep the broken rock in continual motion. A slot and undercut openings equivalent to nominally $10 \%$ of the total deposit volume is first blasted and withdrawn to provide room for expansion to permit blasting the entire remainder of the deposit thereby rubblizing it for leaching. The degree of fragmentation achievable is, in general, a 
function of the quantity of explosive used. The slot muck removed from the drawpoints is hauled to surface and temporarily stockpiled prior to being eventually dumped on top of the blasted deposit.

The top of the entire fragmented deposit is then sprayed with leaching solution using high pressure nozzles to spread the leachate over the entire surface of the blasted deposit. The solution percolates through the rock mass down to the drawpoints which act as collection points to direct the pregnant solution to sumps. The pregnant solution is then be pumped to a surface recovery plant from which the desired metals are recovered. Barren solution is recycled to the top of the deposit. Blasted rock is continually drawn from the drawpoints throughout the life of the operation but at a very slow rate. Only sufficient rock is removed to keep the rock mass in a "constant" state of mixing. Over the life of the operation it is anticipated that only about $10 \%$ to $15 \%$ of the total rock mass will be mucked and hauled to surface and placed on top of the muck pile. The above sequences of activities are illustrated as Stages 1 to 4 . Four figures are provided for each stage depicting the ongoing activities in plan, cross-section and vertical longitudinal projection with explanatory comments annotated on the sketches to highlight the state of events for each particular stage (see the appendix for the complete set of 16 figures).

By establishing a system of drawpoints beneath a leachable deposit, capital and operating costs are dramatically reduced in comparison with a conventional heap leach operation and the drawbacks associated with other proposed in-situ leaching methods are overcome. Specifically, aeration, solution channeling, solution collection, environmental contamination by leach solutions and porosity issues are alleviated by the continual movement of the blasted rock due to mining extraction through the drawpoints. Oxygenation of the rock mass occurs naturally due to the exothermic nature of the leaching process which draws air upwards by convection through the broken rock thereby aerating the mass while simultaneously providing ventilation throughout the underground workings.

The environmental disturbance using this methodology is minimal as there is very little need for surface disturbance initially and ultimate reclamation only requires replacing the original topsoil back on top of the leached deposit, removing the extraction plant and placing a small concrete plug in the decline collar. If warranted, all facilities could be located underground.

\section{Heap Leaching Technology}

Heap leaching technology has advanced rapidly in recent years. However, standard heap leaching operations are still plagued by a number of limiting technical factors. The leachability of any particular deposit is unique to that deposit and is a function of rock porosity and mineralization type. Some deposits are refractory and do not leach well under any conditions while others contain metal hosted in unoxidized sulfides or encapsulated in silica (quartz). Notwithstanding the above, many deposits are leachable and technology has been developed to predict the leachability and leach rates of any given deposit. The leachability of any deposit is usually only affected by the particle size being leached, which defines that amount of desired metal that can be leached over a given period of time, and the presence or absence of clay minerals that cause blinding in the heaps. Ore may be heap leached as run-of-mine or after crushing to optimize the economics of the operation. In practice, heap leaching operations typically are designed to extract approximately $70 \%$ of the contained metal over about a 12 month period. Heap leaching pads must be designed around the above parameters. A particle 
size is selected as optimal for the operation and the run of mine ore may need to be crushed in order to reduce it to a size that will permit a reasonable extraction over a 9 to 12 month period. Leach pads must be designed so that minimal compaction occurs as compaction hampers aeration within the heap as well as being one cause of solution blinding, pooling, and channeling. When the ore needs to be finely crushed prior to leaching or contains sufficient clay minerals to hamper leaching, the ore is frequently agglomerated to overcome these obstacles.

Heap leaching testwork can predict, with reasonable accuracy, how quickly a deposit will leach. Usually this testwork is only undertaken to project leach rates over a maximum one (1) year period. It is known that leaching follows an exponential decay curve and that leaching will continue theoretically until all the metal has been leached. The time frame involved for complete leaching to occur is very long. The new concept presented herein will take advantage of very low operating costs to be able to undertake continuous leaching of the ore for a period that may stretch to 20,30 or more than 50 years.

\section{Fragmentation}

As mentioned above, leaching rates are generally a function of ore characteristics, particle size and leach time. Heap leaching operations are usually large operations using big equipment to handle material. Drilling and blasting is undertaken to reduce the ore to a size that can easily be handled by the equipment fleet. When big open pit equipment is used, the largest boulder that can be handled can weigh many, many tonnes so drilling and blasting is undertaken with this in mind. Open pit blasting usually employs a powder factor of around 0.20 pounds of explosive per ton of ore to achieve the desired level of fragmentation. Underground mining faces different operating conditions and must undertake drilling and blasting operations to reduce the ore size to "hat size" so that it will not hang up in ore passes and chutes. In order to do this, underground operations employ a higher powder factor in the order of 0.40 to 0.60 pounds per ton. Drilling and blasting technology has advanced to the point that combined with geotechnical and electronic advances, it is possible to predict with a high degree of accuracy the particle size distribution that will result under a given set of drilling and blasting conditions. Recent advances in the ability to embed computer chips in blasting caps have enabled technicians to undertake very precise blasting that produces very fine fragmentation with very little oversized material. Agnico Eagle's LaRonde Mine employs this technology and has been able to reduce their stope blasting to only two (2) blasts per complete stope. The resulting fragmentation is exceptional.

The new in-situ leaching concept described herein will make use of this technology in combination with leachability testwork to fragment the ore body in-situ to the desired particle size distribution. It should be noted that the use of explosives energy is a very inexpensive means of breaking rock. AN/FO costs about $\$ 0.35$ per pound. Using a powder factor in the order of 1.0 pounds per ton would result in very fine fragmentation of the in-situ ore so that in-situ leach rates could be comparable to or better than heap leach rates. The degree of fragmentation is simply a function of drill hole spacing and powder factor.

Most of the previous approaches to fragmentation for in-situ leaching attempted to increase permeability and leachability by creating fractures in the rock mass through hydrofraccing, explosives and even thermonuclear devices to fracture and heave the rock mass. The new concept employs standard underground mining practices to create a void representing about $10 \%$ to $15 \%$ of the total volume of rock to be broken. This provides sufficient void space for the ensuing mass blast to expand during the blasting process. The resulting broken rock will 
heave on the surface of the blasted area by approximately 6.1 to 9.1 meters (20 to 30 feet) while creating a void space within the broken material of about $35 \%$ to $45 \%$. The particle size distribution will be predictable.

The ore removed through underground mining activities undertaken to prepare the void space needed to produce the desired fragmentation will be emplaced on top of the heaved muck pile on surface and the total deposit will then be leached.

The conceptual deposit used herein assumes for simplicity's sake that the deposit bottoms out at the 91 to 152 meter (300 to 500 foot) depth. Present drilling technology is capable of drilling to this depth with minimal deviation. Deeper drilling would require specialized drill control techniques or multiple phases of drilling and blasting coupled with the establishment of one or more intermediate drilling horizons which are entirely possible but would unnecessarily complicate the simple concepts this paper is attempting to present.

\section{Leaching}

Leach solutions will be sprayed over the top of the broken material and be allowed to trickle through the blasted rock leaching metals encountered along their path. Channeling will occur and not all of the rock mass will be whetted initially. Knowing the leach rates from the leaching test work and the predicted particle size distribution, one will be able to assess the extent of channeling during the initial leaching of the deposit.

While leaching is under way, the blasted rock mass will be slowly moved downward by withdrawing broken material from the draw points on a daily basis. Over the life of the operation it is anticipated that only about $15 \%$ of the broken rock will need to be withdrawn to be able to create sufficient movement with the blasted material to permit all of the broken ore to be wetted. The draw point system array is similar to those used for underground block caving operations. Draw control at underground block caving operations is practiced with a great deal of care in order to draw down the ore evenly so that intermixing of waste with the ore and loss of ore intermixed within the waste is minimized. Even with careful draw control, ore recoveries in the $85 \%$ range accompanied by about $15 \%$ dilution are the norm for block caving operations. Considerable work has been done to identify the conditions under which intermixing occurs during block cave mining and considerable effort is expended to avoid creating these conditions. The slow removal of material envisaged in this new in-situ leach concept does not employ the same draw control parameters. Instead, intermixing of the material is preferred. Draw points will be mucked in a sequence that causes the most intermixing. The ore will also undergo further fragmentation during the process of movement within the column. The constant movement taking place within the rock mass will reroute solutions and minimize channeling and also serve to flush out fine material to the draw points located at the bottom of the zone. While the actual leaching rates cannot be predicted at the moment, the process can eventually expose all of the broken rock to leaching solutions.

The new in-situ leaching concept presented herein solves the problems of solution channeling that has plagued previous attempts and also addresses the problem of blinding due to fines. The fines that are flushed out will eventually settle in the underground sumps and be pumped to surface where they will be held until the end of the mine life whereupon they will simply be added to the top of the ore pile as part of the final mine rehabilitation activities.

It is known that some forms of copper sulfides are difficult to leach under the short leach times encountered in heap leaching. It is not known how copper species such as chalcopyrite will 
leach under conditions where they are being leached for 20 or 30 years. This new concept may provide a means to leach chalcopyrite.

\section{Aeration}

The presence of approximately $40 \%$ void space in the broken material coupled with the heat generated through exothermic reactions will produce natural ventilation through the rock mass that will provide oxygen to aid in reaction kinetics. The dissolution of gold requires oxygen while copper leaching requires oxygen to generate acid from sulfides contained in the ore. The airflow through the rock mass can be controlled because it must enter through the decline access which can be restricted to reduce airflow or pressurized using air fans to increase the airflow. Aeration within heap leaching pads is an issue that restricts the thickness one can emplace upon a given pad and has been the subject of many attempts to improve oxygenation of leach pads through injection of oxidizing chemicals or air through drill holes and pipes as well as using explosives to heave leach pads to alleviate blinding, channeling and improve oxygenation. This new concept provides a simple, low cost and effective means of solving another of the major problems encountered during heap leach operations.

\section{Leach Solution Collection and Containment}

Previous in-situ leaching attempts usually envisaged collection of pregnant solution via drill holes drilled beneath or adjacent to the material being leached. In this new concept, the deposit is completely undercut during the preparation of the draw points and undercuts. Assuming that the deposit is nearly vertical, all solutions must flow by gravity ultimately to the draw points at the bottom of the deposit. All of the underground tunnels will be driven at a slight uphill slope from the collection sump so that all of the pregnant solutions will drain to the sump. This new concept initially envisages locating the draw points at or slightly below the oxide/sulfide interface which is generally at the water table. With the draw point located below the water table and no static head being developed in the leach column, any fugitive flows should be INTO the draw point system from the surrounding groundwater. Solutions should not be able to enter the groundwater if the draw points are located below the water table. Similarly, the blasted perimeter walls of the in-situ leach column actually will form the containment and reaction vessel in which leaching takes place. It is envisaged that the walls of the vessel will be vertical or inclined slightly outward as it progresses to depth so that gravity effects will naturally force any leach solutions to shy away from the walls. In this way, any ground water flows will be inflows into the leach column not leach solution outflows into the surrounding environment.

Inflow of ground water could result in dilution of the pregnant leach solution and water balance modeling will be an important aspect of more detailed design of the new in-situ leaching system. 


\section{ECONOMICS OF THE NEW CONCEPT}

\section{Summary}

Tables 9.1 and 9.2 illustrate the comparable capital and operating costs associated with in-situ leaching for a typical 20 and 40 million tonne heap leachable oxide gold deposit. The capital costs to undertake in-situ leaching are roughly $40 \%$ to $60 \%$ of the capital costs required establishing a standard heap leaching operation and the operating costs are very low as very little material is moved on an annual basis.

Although existing technology can predict leaching rates and recoveries for run of mine ores and heap leaching in pads, little data is available to accurately predict in-situ leaching rates and recoveries using the proposed system. The economics of this in-situ leaching method is based on an estimation of how much recovery is needed from the overall deposit in order to recoup capital costs and how much recovery is needed annually in order to cover operating costs. Recovery of less than $10 \%$ of the in-situ contained metal will pay for the initial capital costs while operating costs can be recouped from as little as $1.0 \%$ to $1.5 \%$ annual recovery of the insitu contained metal.

Rapid payback is anticipated as all of the deposit is brought under leach within a short time frame as opposed to heap leaching where the ore is mined and treated over a 7 to 10 year mine life. The up front capital costs are estimated to be recovered by leaching only $10 \%$ of the contained metal in the case studies.

\section{Capital Costs}

Capital costs have been estimated based on known costs for other projects with which we have been involved. The mine development costs assume that the operator provide the equipment and facilities and contracts the labor and materials component. The capital costs for this new concept are much lower than for a conventional heap leaching operation primarily due to the minimal infrastructure required for the concept. Based on a comparison to the capital requirements for a known 50 million tonne heap leach gold deposit, the capital costs are in the order of $40 \%$ of that needed for conventional heap leaching. Based on less than $10 \%$ recovery of the contained metal over a one year operating period, all capital would be repaid.

The capital cost estimate for the metal recovery plant is based in the example cases on the estimated cost for a carbon adsorption-desorption-regeneration (ADR) plant for gold. An SXEW plant for copper recovery would cost somewhat more.

\section{Operating Costs}

Operating costs for this new in-situ leach concept are expected to be very low. Operating costs have been estimated based on standard US wage rates for mining and equipment operating costs. Very few people are needed to operate once the project is in production. One man per shift is needed to operate the processing plant and 2 men are needed on only one shift per day, five days per week to muck the draw points and service the topside dump and spray nozzles. The operating costs to keep the ore in motion and operate the gold recovery plant will be in the $\$ 3$ to 4 million per year range and require less than $1 \%$ recovery of the contained metal to cover operating costs. 


\section{PROJECT PARAMETERS}

Deposit is oxide gold nominally 20 Million tonnes grading $1.5 \mathrm{gm} / \mathrm{T} \mathrm{Au}$

Roughly $200 \mathrm{~m}$ wide by $300 \mathrm{~m}$ long by $150 \mathrm{~m}$ deep

\section{CAPITAL COSTS}

\$ X 1000

Mine Preparation

Decline

$1000 \mathrm{~m} @ \$ 1,500 / \mathrm{m}=$

1,500

Undercuts \& Mucking Drifts

3,500m@\$1,000/m=

$75 @ 10 \mathrm{~m}$ ea@\$1000/m=

150m@\$400/m=

1 Million Tonnes@\$2.00/T=

1 Million Tonnes@\$0.50/T=

2 Million Tonnes@\$2.00/T=

2 Million Tonnes@\$0.50/T=

Move Surface Stockpile

Drill \& Blast Remainder of Orebody

18 Million Tonnes@\$0.40/T

Sub-Total

3,500

750

60

2,000

500

4,000

1,000

13,310

7,200

Sub-Total

7,200

Surface Facilties

Surface Stripping

500,000 cu.m.@\$2.00/m=

Surface Plant (CIL) \& Facilities

Misc. Facilties \& Equipment

TOTAL CAPITAL COSTS

Contingency

TOTAL PROJECT CAPITAL

1,000

4,000

2,000

Sub-Total

7,000

27,510

2,490

30,000

\$000/YR

1,000

1,500

250,000T/yr@\$2.00/T

500

1,000

$\mathbf{4 , 0 0 0}$

TOTAL OPERATING COSTS
$\$ \times 1000$

300,000

$10.0 \%$

$1.33 \%$ 


\section{MILLION TONNE OXIDE} GOLD DEPOSIT

\section{PROJECT PARAMETERS}

Deposit is oxide gold nominally 40 Million tonnes grading $1.5 \mathrm{gm} / \mathrm{T} \mathrm{Au}$

Roughly $300 \mathrm{~m}$ wide by $400 \mathrm{~m}$ long by $150 \mathrm{~m}$ deep

\section{CAPITAL COSTS}

$\$ X 1000$

Mine Preparation

Decline
Undercuts \& Mucking Drifts
Draw Points
Slot Raise
U/G Drill \& Blast Undercuts
Slot Drill \& Blast
U/G Mucking \& Hauling
Move Surface Stockpile

Drill \& Blast Remainder of Orebody

Surface Facilties

Surface Stripping

Surface Plant (CIL) \& Facilities

Misc. Facilties \& Equipment

\begin{tabular}{|c|c|c|}
\hline $1000 \mathrm{~m} @ \$ 1,500 / \mathrm{m}=$ & & 1,500 \\
\hline $5,000 \mathrm{~m} @ \$ 1,000 / \mathrm{m}=$ & & 5,000 \\
\hline $115 @ 10 \mathrm{~m}$ ea $@ \$ 1000 / \mathrm{m}=$ & & 1,150 \\
\hline $150 \mathrm{~m} @ \$ 400 / \mathrm{m}=$ & & 60 \\
\hline 2 Million Tonnes @ $\$ 2.00 / T=$ & & 4,000 \\
\hline 2 Million Tonnes @ $\$ 0.50 / \mathrm{T}=$ & & 1,000 \\
\hline 4 Million Tonnes@ $\$ 1.50 / \mathrm{T}=$ & & 3,000 \\
\hline 4 Million Tonnes @ $\$ 0.50 / \mathrm{T}=$ & & 2,000 \\
\hline & Sub-Total & 17,710 \\
\hline 36 Million Tonnes @ \$0.40/T & & 14,400 \\
\hline & Sub-Total & 14,400 \\
\hline
\end{tabular}

$1,000,000$ cu. m. @ $\$ 1.50 / \mathrm{m}=$

1,500

6,000

3,000

Sub-Total

10,500

42,610

4,390

47,000

\$000/YR

2,000

1,500

750

1,000

$\mathbf{5 , 2 5 0}$

$\$ X 1000$

600,000

$7.8 \%$

$0.9 \%$

Capital Costs as \% of Gross Value (Breakeven Recovery Needed)

Operating Costs as \% of Gross Value (Breakeven Recovery Needed) 


\section{Economic Viability}

Revenue is difficult to accurately predict given that this concept has never been attempted. In order to gain an insight into the economic potential of the concept, a reverse economic approach has been used. Based on the capital and operating costs estimated, the recovery needed to offset these costs was estimated. As can be seen from Tables 9.1 and 9.2, since the whole orebody is under leach at the outset of production, very little metal need be recovered to recover capital and operating costs.

Assuming a 20 year operating life and an ultimate overall recovery comparable to heap leaching of $70 \%$ (7\% recovery per year), the 20 million tonne deposit would generate a total life of mine revenue of approximately $\$ 210$ million to offset an estimated capital cost of $\$ 30$ million and 20 years of operating costs that would total about $\$ 80$ million for a net operating profit of about $\$ 100$ million or about $\$ 6.5$ million per year of operating profit, (revenue $\$ 10.5$ million less operating costs of $\$ 4$ million) which is a healthy revenue to cost ratio. Similarly, the 40 million tonne deposit would generate a total life of mine revenue of approximately $\$ 420$ million to offset an estimated capital cost of $\$ 47$ million and 20 years of operating costs that would total about $\$ 100$ million for a net operating profit of about $\$ 320$ million or about $\$ 16$ million per year of operating profit (revenue $\$ 21$ million less operating costs of $\$ 5.25$ million).

\section{Applicability of the New Concept}

For purposes of this initial presentation of the concept we have chosen to use a simple base case which assumes a near vertical, oval shaped cylindrical ore zone that comes to surface and is covered with minimal overburden. In addition, it is assumed that the ore zone only reaches a depth of 91 to 152 meters (300 to 500 feet) from surface at which point the water table is present. More complicated geometries can be mined in-situ using this new concept, as can much deeper ore bodies or ore bodies that are capped with waste or heavy overburden. However, an attempt to describe ways that this would be undertaken would complicate the simple concept we are attempt to present.

Although we have written the bulk of this paper stressing its applicability to leachable oxidized copper or gold ore bodies, it could also be applied to many other metals.

\section{Restrictions of the New Concept}

For this new concept to work initially it should not be tried on a polymetallic deposit. The concept should be applied to a heap leachable gold or copper deposit. In the case of a gold deposit, the host rock must not be acid generating or a cyanide consumer. In the case of a copper deposit, the host rock acid consumption characteristics (i.e., reagent consumption) will be critically important in the economic assessment. 


\section{BENEFITS OF THE NEW CONCEPT}

The benefits that may arise from application of the new concept are summarized as follows:

- The new system promises to improve the economics of treating ore deposits that meet the applicability criteria.

- The new ISL concept will likely accelerate the leach rate of the deposit resulting in an economic benefit.

- This system overcomes many of the challenges of in-situ leaching hard rock ores, e.g. copper porphyry deposits, oxide gold and silver deposits, volcanogenic massive sulfides and sediment hosted ores, namely: poor metal recovery due to inadequate fragmentation, inadequate leaching due to fines migration and blinding, inadequate leaching due to solution channeling, poor oxygenation, gas bubble exsolution and blinding of pores, etc.

- By excavating a slot through the ore deposit prior to blasting, provision is made to accommodate the swell factor that occurs during blasting. This results in improved fragmentation of the ore to the point that the fragmentation can be engineered to produce the fragmentation required for optimal metal leach recovery.

- Fines migration within a blasted ore zone subjected to in-situ leaching can result in blinding off zones within the ore deposit. The innovative system described here prevents blinding from occurring, as the entire column is moved and new solution flow patterns are constantly being created.

- When air, oxygen or sulfur dioxide are injected into an in-situ leach system it is possible for gas pockets to form that blind off portions of the deposit preventing solutions from reaching or penetrating into the ore particles immediately adjacent to the gas bubbles. This phenomenon can be expected to be overcome by the new technology since the entire column of blast-fragmented ore is moved on a regular basis thereby establishing a constantly changing flow pattern of oxygenating air and solution through the ore.

- Gases, e.g. air and oxygen are pumped into the leach system via the access decline and introduced via the bottom of the column of ore undergoing leaching. The rate of oxidation and bio-oxidation of sulfides within the ore being treated can be controlled by 1) the rate of oxygen or air injection, and 2) the rate at which lixiviant solution is applied to the top of the column of fragmented ore.

- The new concept provides a much more controllable environment for bacterial oxidation of sulfide minerals, and for solution and oxygen contact with the fragmented material in the ore column.

- The new concept configuration, with the ability to cause movement within the ore column, provides a means of more efficient rinsing of the spent ore column on completion of the project, if rinsing is a requirement for reclamation and closure. 


\section{WHAT NEEDS TO BE DONE NEXT?}

These are key steps to be taken in order to further develop the new concept outlined in this white paper:

1. Find one or more potential sites where the new in-situ leach concept can potentially be tested.

2. Carry out a conceptual design study of how the new in-situ leach concept could be applied for one or more real-life sites.

3. Future development work to focus on "hard rock" applications. This could most likely be for gold, silver, copper, nickel, zinc sulfide, or possibly manganese deposits. Also, breccia pipe deposits of base metal sulfides and uranium could be considered.

4. In order to advance the new concept, it will be helpful to enlist the assistance of engineers and scientists who have prior experience in in-situ leaching and metal recovery from leach solutions.

5. Prime focus should be given to at least the following aspects seeking to apply the new concept in-situ leach system to a real life ore deposit:

- Geometry of the system

- Applying the new concept to improving permeability of the ore to be leached

- Lixiviant and mobilized metal ion containment

- Application techniques for bio-oxidation (if applicable)

- Application to thermophilic biooxidation of chalcopyrite; reduction of plugging due to biomass or gypsum formation

- Solution application system

- Solution collection and pumping system

- Air injection system

- Air flow control system

- Metallurgical balance management system

- Reagent balance management system

- Practical aspects of the solution flow pattern adjustment system.

- Closure and reclamation aspects, particularly prevention of ingress of air and water and permanent protection of groundwater.

- Application to both oxide and sulfide ores 


\section{SUMMARY AND CONCLUSIONS}

Key findings and issues related to developing an expanded application of in-situ leaching by using the new concept described in this white paper are summarized as follows:

- In-situ leaching in practice is more difficult than expected from theory.

- Many of the patents issued over the last 30 to 40 years appear bordering on the impossible today in terms of realistic potential for adoption.

- Anyone developing an in-situ leaching operation would benefit significantly from the assistance of individuals who have practical experience in the field.

- In-situ leaching invariably requires adaptation for site-specific conditions.

- Oxygen and/or air are the preferred oxidants for most ISL projects.

- Peroxide has also been shown to be a good oxidant in laboratory scale tests, but is believed to be too expensive to be economically practicable for commercial scale operations.

- Ferric ions are also an effective oxidant and may be generated using an external, abovesurface bioreactor or biologically in-situ.

- The new ISL concept has the potential to expand the applicability of ISL, especially in the extraction of gold, silver, copper, nickel and other base metals from near surface deposits.

- There will be site-specific constraints to the application of the new ISL concept:

1) The deposit needs to be sufficiently near-surface for the top of the column of fragmented ore to be accessible to leach solutions applied at the surface using sprays.

2) The deposit needs to be located in such a manner that PLS can be efficiently collected below the fragmented ore column. It may be contained within a body of massive gangue such that solutions cannot escape or the base of the fragmented ore column needs to be within or close to the water table such that a cone of depression within the aquifer can be used to collect PLS. 


\section{REFERENCES}

Bampton, K.F., Bologiannis F., Canterford, J. H., and Smith A.N. (1983) Development of experimental in-situ leaching at the Mutooroo copper mine, South Australia. AusIMM Annual Conference, Broken Hill, NSW July 1983, pp. 371-379.

Bartlett, R.W. (1992) Solution Mining: Leaching and Fluid Recovery of Materials. Amsterdam, Gordon and Breach Science Publishers.

Bartlett, R.W. (1998) Solution Mining: Leaching and Fluid Recovery of Materials, $2^{\text {nd }}$ Ed. Amsterdam, Gordon and Breach Science Publishers.

Bates, R.L. and Jackson, J.A., eds. (1987) Glossary of Geology, $3^{\text {rd }}$ edition, Alexandria, Va., American Geological Institute.

Batterham, R. (2004) Has minerals industrial technology peaked? Presented at the Annual meeting of the Society for Mining, Metallurgy, and Exploration, Inc., Denver, Colo., February, 2004.

Beane, R. (1999) Challenges facing in-situ leach solution chemistry. Proc. Randol Copper Hydromet Roundtable 1999, Phoenix, Ariz., Oct. 1999, pp 51-53.

Beane, R. and Ramey, D. (1995) In-situ copper leaching at the San Manuel porphyry copper deposit, Arizona, USA. In: Cooper, W.C., Dreisinger, D.B., Dutrzac, J.E., Hein, H. and Ugarte, G., eds., Proc. Copper 95 International Conference, v.III, pp 363-375.

Bell, A. (1984) Checking the safety of solution mining. Ecos. 39: 19-22.

Brierley, C.L. and Brierley, J.A. (2000) Bioheap processes: operational requirements and techniques. Proc. Randol Copper Hydromet Roundtable 2000, Tucson, Ariz., Sept. 2000, pp 95103.

Bruynesteyn, A. (2000) Report on chalcopyrite bioleaching. Proc. Randol Copper Hydromet Roundtable 2000, Tucson, Ariz., Sept. 2000, pp 113-117.

Campbell, S.C., Olson, G.J., Clark, T.R., and McFeters, G.A. (2001) Biogenic production of cyanide and its application to gold recovery. J. Indust. Microbiol. 26: 134-139.

Coursen, D.L. (1976) In-situ leaching of explosively fractured ore deposits. US patent 3,999,803.

Coyne, K.R. and Hiskey, J.B. eds. (1989) In-Situ Recovery of Minerals. New York, United Engineering Foundation.

Geisler, R.A. and Pudington, I.E. (1996) Treatment of lead sulfide bearing minerals. US Patent $5,523,066$. 
Girard, L and Hart, R.A. (1974) Stimulation of production well for in-situ metal mining. U.S. Patent 3,841,705.

Graves, C.W. (1985) In-situ recovery of mineral values. U.S. patent 4,561,696.

Hancock, S. (1988) In-situ leach mining: the next quantum leap? $3^{\text {rd }}$ International Mine Water Congress, IWWA and AusIMM, Melbourne, October 1988, pp 883-889.

Hore-Lacy, I. (1982) New gold mining technique for Victoria's deep leads. Lab Talk, Dec 1982. Science Teachers Association of Victoria (STAV), pp 26-30.

Hunkin, G.G., Fife, T.P., and Stano, J.R. (1979) In-situ carbonate leaching of uranium from ore deposits. U.S. Patent 4,155,982.

Hurd, B.G. and Fitch, J.L. (1966) In-situ leaching of subterranean deposits. U.S. Patent $3,278,233$.

Ismay, A., Rosato, L., and McKinnon, D. (1986) Engineering prefeasibility for in-place bacterial leaching of copper, pp. 191-198, in: Fundamental and Applied Biohydrometallurgy, R.W. Lawrence, R.M.R. Brannion and H.G. Ebner, eds., Amsterdam, Elsevier.

Jacobson, R.H., Murphy, J.W., and Queneau P.B. (1989) A review of solution mining — part 3. In situ and heap leach mining. Min. Res. Eng. 2: 163-187.

Jacoby, C.H. (1974) In-situ extraction of mineral values from ore deposits. U.S. Patent 3,822, 916.

Jones, A.H and Greene, S.J. (1986) Process for solution mining. U.S. Patent 4,561,696.

Landmark, J. (1992) Gunpowder Copper Ltd: in-situ leaching at Mammoth mine, NW Queensland. AuIMM Bull. 6: 12-13.

Lovley, D.R. 2000. Environmental microbe-metal interactions. Washington, American Society for Microbiology Press.

Liu, J and Brady, B.H. (1998) Evaluation of velocity-dependent in-situ leaching processes: single-porosity model. Metall. Mater. Trans. B. 29B: 1227-1234.

McCready, R.G.L. and Gould, W.D. (1990) Bioleaching of uranium, in Microbial Mineral Recovery, eds. H.L. Ehrlich and C.L. Brierley, pp 107-126, New York, McGraw- Hill.

Middlin, B \& Meka, Z. (1993) Design and operation of the Gunpower Copper Ltd's in-situ leach-SX-EW process. AusIMM Centenary Conference, AusIMM, Adelaide. March 30-April 4, pp 183-187.

Miller, David (2004) Personal communication, Strathmore Minerals Corp., Riverton, Wyo. 
Mineev, G.G. and Shutov, A.M. (1979) Feasibility of mining gold by underground placer leaching (English Translation). Soviet Mineral Sci. 15: 400-404.

Morris, L.J. (1984) Solution Mining. $8^{\text {th }}$ Australian Groundwater School, vol 2, ch 14, Australian Mineral Foundation, Adelaide, Aug 27 - Sept 7.

Mudd, G. M. (2001a) Critical review of acid in-situ leach uranium mining: 1. USA and Australia. Environ. Geol. 41: 390-403

Mudd, G. M. (2001b) Critical review of acid in-situ leach uranium mining: 2. Soviet Block and Asia. Environ. Geol. 41: 404-414.

Mulhaus, H.B., Liu, J., and Hobbs, B.E. (1999) A porosity evolution model for in-situ leaching process. Proc. $2^{\text {nd }}$ Australia Congress on Appl. Mathematics, Canberra, Feb. 1999, pp. 488-495.

The National Academy of Sciences (2002) Evolutionary and Revolutionary Technologies for Mining, pp. 33-37, Washington, DC, National Academy Press.

Ness, V. (2000) Basic principles, processes, chemistry and hardware for copper SX-EW. Randol Copper Hydromet Roundtable 2000, Tucson, Ariz., Sept. 2000, pp 227-232.

Norton, G.A., Richardson, R.G., Markuszewski, R., and Levine A.D. (1991) Precipitation of jarosite compounds as a method for removing impurities from acidic wastes from chemical coal cleaning. Environ. Sci. Technol. 25: 449-455.

Olson, G.J., Dockins, W.S., McFeters, G.A., and Iverson W.P. (1981) Sulfate-reducing and methanogenic bacteria from deep aquifers in Montana. Geomicrobiol. J. 2: 327-340.

Olson, G.J., Clark, T.R., and Kelso, J. (1998) Biooxidation of Metates ore using thermophilic microorganisms. Proc. Randol Gold and Silver Forum '98, Denver, Colo., April, 1998, pp. 261265.

Olson, G.J., Clark, T.R., Osborne, H.C., and Dick, L.A. (2000) General Minerals Vizcachitas project: bioleaching of chalcopyrite concentrate and low grade ore. Proc. Randol Copper Hydromet Roundtable 2000, Tucson, Ariz., pp. 141-143.

Olson, G.J., Brierley, J.A. and Brierley, C.L. (2003) Bioleaching review part B: progress in bioleaching: applications of microbial processes by the minerals industries. Appl. Microbiol. Biotechnol. 63: 249-257.

Pinches, A., Myburgh, P.J., van der Merwe, C. (2001) Process for the Rapid Leaching of Chalcopyrite in the Absence of Catalysts. U.S. patent 6,277,341 B1.

Pool, Thomas (2002) Nuclear Fuels Corp., Littleton, Colo., Personal communication. 
Rossi, G., Trois, P., and Visca, P. (1986) In-situ pilot semi-commercial bioleaching test at the San Valentine di Predoi mine (Northern Italy) pp. 173-189, In: Fundamental and Applied Biohydrometallurgy, R.W. Lawrence, R.M.R. Brannion and H.G. Ebner, eds., Amsterdam, Elsevier.

Sand, W., Gehrke, T., Hallmann, R., Rohde, K., Sobotke, B.,and Wentzien, S. (1993) In-situ bioleaching of metal sulfides: the importance of Leptospirillum ferrooxidans, pp. 15-27, in Biohydrometallurgical Technologies, A.E. Torma, J.E. Wey, V.L. Lakshmanan, eds., Warrendale, Penn., The Minerals, Metals and Materials Society.

Schlitt, W.J. and Hiskey, J.B., eds. (1981) Interfacing technologies in solution mining, pp 370, in: Proc. $2^{\text {nd }}$ SME-SPE International Solution Mining Symposium, New York, AIME.

Schlitt, W.J. and Shock, D.A. eds. (1979) In-situ uranium mining and ground water restoration. Proc. AIME-SME Annual Meeting, New Orleans, La., p. 137.

SME (2003) Solution mining of nahcolite at the American Soda project, Piceance Creek, Colorado, Proc. 2003 SME Annual meeting, Cincinnati, Ohio.

Spence, J. R. (2000) Extractant considerations in copper SX-EW. Proc. Randol Copper Hydromet Roundtable 2000, Tucson, Ariz., pp. 233-237.

Uhrie, J.L. (2000) A review of secondary sulfide leaching. Proc. Randol Copper Hydromet Roundtable 2000, Tucson, Ariz., pp. 107-111.

United States Department of Energy (1999) Uranium Industry Annual 1998, U.S. Department of Energy (DoE), Washington, DC, DOE/EIA-0478(98).

Uranium Information Center (2001). In-situ leach mining of uranium. Nuclear Issues Briefing Paper 40, November, 2001. www.uic.com.au/nip40.htm

Van Poolen, H.K. and Huff, R.V. (1975) Oxidation of sulfide deposits containing copper values. US Patent 3,881,774.

von Michaelis, H. (2004) Personal Communications, Randol International Ltd., Golden, Colorado. (303) 526-1626

Yates, M.V., Brierley, J.A., Brierley, C.L., and Follin, S. (1983) Effect of microorganisms on in situ uranium mining. Appl. Environ. Microbiol. 46: 779-784.

Young, S. K. (1999) Bioleaching of chalcopyrite ores. Proc. Randol Copper Hydromet Roundtable 1999, Phoenix, Ariz., Oct. 1999, pp. 61-62.

Young, S. K. (2000) Personal communication on June 14, 2000 as reported in National Academy of Science (2002). 
Wadsworth, M.E. (1983) Metallurgy: Past, present and future. pp 3-38, in: Proc. $3^{\text {rd }}$ International Symposium on Hydrometallurgy, ed. K. Osse and J.D. Miller, New York, AIME.

ZoBell, C.E. (1958) Ecology of sulfate reducing bacteria. Producers Monthly 22: 12-29.

Contacts : In-Situ experts

Sharon Young, Versitech Inc, Tucson, AZ

$520 / 742-1239$

1438 W. San Lucas, Tucson, AZ 85704-1122

skyvtec@aol.com

David Miller, Riverton, WY

307/857-5789; 307/851-6305

Paul Chamberlin, Chamberlin \& Associates

$303 / 979-6753$

Ian Ewart, Electrowinning International Ltd., Vancouver

604/506-0019; 604/904-0442

Bob Washnock, Constellation Copper,

435/259-3077

P.O. Box 847, Moab, UT 84532

Dan Raimey, Hydrologist, Mining Solutions Inc

raimeyds@miningsolutionsinc.com, or

raimyda@miningsolutions.com

Joseph R. Stano

303/986-6698

9430 W Mexico Ave, Lakewood, CO 80232

Wayne C. Henderson, Dyna Resource Ltd.

5215 N. O'Connor Rd, Suite 200, Irving, TX 75039

Home in West Virginia

540/839-6374

Steve Axen, Ray Huff \& Associates

$303 / 278-1408$

2191 Braun Drive, Golden, CO 80401

Ray Huff, Ray Huff \& Associates

$520 / 227-7052$

P.O. Box 1114, Hereford, AZ 85615

Mike Eman, BHP Houston (familiar with the Magma Copper Florence, AZ in situ leaching operation and those involved).

Craig Bartles, formerly of URI

Anton Hendricksz, former VP, E.L. Bateman, retired in S. Africa

Wallace Mayes, formerly of URI, Texas. 


\section{APPENDIX}

Figures (16 total) Illustrating New Concept on an Idealized 20mT Oxidized Orebody:

Stage 1

Surface Plan View (CD file name: 1-STAGE1-SURF)

Plan View of Underground Workings (2-STAGE1-UG)

L-L' of Underground Workings (3-STAGE1-L)

$\mathrm{X}-\mathrm{X}$ ' of Underground Workings (4-STAGE1-X)

Stage 2

Surface Plan View (CD file name: 5-STAGE2-SURF)

Plan View of Underground Workings (6-STAGE2-UG)

L-L' of Underground Workings (7-STAGE2-L)

$\mathrm{X}-\mathrm{X}$ ' of Underground Workings (8-STAGE2-X)

Stage 3

Surface Plan View (CD file name: 9-STAGE3-SURF)

Plan View of Underground Workings (10-STAGE3-UG)

L-L' of Underground Workings (11-STAGE3-L)

$\mathrm{X}-\mathrm{X}^{\prime}$ of Underground Workings (12-STAGE3-X)

Stage 4

Surface Plan View (CD file name: 13-STAGE4-SURF)

Plan View of Underground Workings (14-STAGE4-UG)

L-L' of Underground Workings (15-STAGE4-L)

$\mathrm{X}-\mathrm{X}^{\prime}$ of Underground Workings (16-STAGE4-X) 